NBER WORKING PAPER SERIES

\title{
OPTING OUT OF THE GREAT INFLATION: GERMAN MONETARY POLICY AFTER THE BREAK DOWN OF BRETTON WOODS
}

\author{
Andreas Beyer \\ Vitor Gaspar \\ Christina Gerberding \\ Otmar Issing \\ Working Paper 14596 \\ http://www.nber.org/papers/w14596 \\ NATIONAL BUREAU OF ECONOMIC RESEARCH \\ 1050 Massachusetts Avenue \\ Cambridge, MA 02138 \\ December 2008
}

We thank Edward Nelson and Athanasios Orphanides for sharing their real-time output gap data with us. Furthermore, we thank our discussant Benjamin Friedman for his challenging and thought-provoking comments. We are also grateful to Michael Bordo, Vítor Constancio, Gabriel Fagan, Dieter Gerdesmeier, Alfred Guender, Lars Jonung, Athanasios Orphanides, Werner Roeger, Franz Seitz, Ulf Söderström, Lars Svensson, Guntram Wolff, Andreas Worms and Charles Wyplosz for insightful discussions and their valuable suggestions. We also wish to thank participants of a seminar held by the Eurosystem's MPC and participants of the NBER conference at Woodstock for their comments that helped improving an earlier draft of this paper. Last but not least we would like to express our gratitude to Aurelie Therace for her efficient help in preparing the final manuscript. The views expressed herein are those of the author(s) and do not necessarily reflect the views of the National Bureau of Economic Research.

NBER working papers are circulated for discussion and comment purposes. They have not been peerreviewed or been subject to the review by the NBER Board of Directors that accompanies official NBER publications.

(C) 2008 by Andreas Beyer, Vitor Gaspar, Christina Gerberding, and Otmar Issing. All rights reserved. Short sections of text, not to exceed two paragraphs, may be quoted without explicit permission provided that full credit, including $\odot$ notice, is given to the source. 
Opting Out of the Great Inflation: German Monetary Policy After the Break Down of Bretton Woods

Andreas Beyer, Vitor Gaspar, Christina Gerberding, and Otmar Issing

NBER Working Paper No. 14596

December 2008

JEL No. E31,E32,E41,E52,E58

\begin{abstract}
$\underline{\text { ABSTRACT }}$
During the turbulent 1970s and 1980s the Bundesbank established an outstanding reputation in the world of central banking. Germany achieved a high degree of domestic stability and provided safe haven for investors in times of turmoil in the international financial system. Eventually the Bundesbank provided the role model for the European Central Bank. Hence, we examine an episode of lasting importance in European monetary history. The purpose of this paper is to highlight how the Bundesbank monetary policy strategy contributed to this success. We analyze the strategy as it was conceived, communicated and refined by the Bundesbank itself. We propose a theoretical framework (following Söderström, 2005) where monetary targeting is interpreted, first and foremost, as a commitment device. In our setting, a monetary target helps anchoring inflation and inflation expectations. We derive an interest rate rule and show empirically that it approximates the way the Bundesbank conducted monetary policy over the period 1975-1998. We compare the Bundesbank's monetary policy rule with those of the FED and of the Bank of England. We find that the Bundesbank's policy reaction function was characterized by strong persistence of policy rates as well as a strong response to deviations of inflation from target and to the activity growth gap. In contrast, the response to the level of the output gap was not significant. In our empirical analysis we use real-time data, as available to policy-makers at the time.
\end{abstract}

\author{
Andreas Beyer \\ European Central Bank \\ Postfach 160319 \\ D-60066 \\ Frankfurt am Main \\ Germany \\ andreas.beyer@ecb.int \\ Vitor Gaspar \\ Banco de Portugal \\ Special adviser \\ Av. Almirante Reis, 71 - 8 \\ 1150-012 Lisboa \\ Portugal \\ vitor.gaspar@ec.europa.eu
}

\author{
Christina Gerberding \\ Deutsche Bundesbank \\ Monetary Policy Division \\ D-60431 Frankfurt am Main \\ christina.gerberding@bundesbank.de \\ Otmar Issing \\ Centre for Financial Studies \\ Goethe University Frankfurt \\ Mertonstrasse 17-25 \\ D-60325 Frankfurt am Main \\ Germany \\ wue@otmar-issing.de
}




\section{Introduction}

In the second half of the twentieth century, the German Bundesbank established its reputation as one of the most successful central banks in the world. Along with the Swiss National Bank, the Bundesbank was the first central bank to announce and pursue a strategy based on monetary targets after the breakdown of Bretton Woods. In this paper, we relate the Bundesbank success in maintaining price stability and in anchoring inflation expectations to its strategy. We examine the strategy as it was presented, refined and communicated by the Bundesbank itself. Our goal is to provide a historical account of the conduct of monetary policy, focusing especially on the first ten years of monetary targeting, from 1975 until the middle of the 1980 s, when price stability was virtually reached in Germany.

According to the Bundesbank Act the objective of monetary policy is to safeguard the currency. The Bundesbank has always interpreted its mandate as giving precedence to (domestic) price stability. It is, therefore, clear that monetary targets were intermediate targets. They were instrumental to achieving price stability. Helmut Schlesinger (1988) - as quoted in von Hagen (1995) - made the point crystal clear:

"... the Bundesbank has never, since 1975, conducted a rigid policy geared at the money supply alone; all available information about financial markets and the development of the economy must be analyzed regularly ... Furthermore, the Bundesbank had to check the consistency of her original monetary targets with the ultimate policy goals."

Moreover, the Bundesbank's operational framework for monetary policy implementation implied that the first step in the transmission mechanism was the control over a money market interest rate. Thus, in this paper, we characterize the Bundesbank's monetary policy strategy through an interest rate rule in the tradition of Taylor $(1993,1999)$, modified to take account of the implications of monetary targeting for the Bundesbank's interest rate decisions. The issue has already been repeatedly considered in the literature (e.g. Clarida et al., 1998, Gerberding et al., 2005). 
The central role of monetary policy in anchoring inflation and inflation expectations was recognized as crucial by the Bundesbank early on. Such concern is transparent in the mechanics of the derivation of the monetary target. From this viewpoint, central banking practice progressed ahead of theory's emphasis on credibility and reputation (as developed later in the work of Kydland and Prescott, 1977; Barro and Gordon 1983a, 1983b).

In the last fifteen years, the new neoclassical synthesis and new Keynesian models became the workhorse for the theory of monetary policy-making (see Woodford, 2003, and Galí, 2008, for authoritative, book length, surveys). ${ }^{1}$ These models rely on a Real Business Cycle core. They add on price setting by monopolistic competitive firms subject to some constraint or cost on price changes, leading to nominal stickiness. Another key feature is that economic agents form expectations in a forward-looking way, taking into account what they know about the central bank's reaction function. Hence, despite their well-known limitations, these models provide a natural environment to discuss commitment, credibility and reputation (see, for example, Gaspar and Kashyap, 2007).

Building on the modified loss function approach (pioneered by Rogoff, 1985), we will show in this paper how focusing on money growth helps to bring the conduct of monetary policy closer to optimal policy under commitment (thereby improving on the outcome under discretion). It does so by inducing a persistent, history-dependent response of policy rates to deviations of inflation and output from target. Therefore, it allows us to rationalize monetary targeting as a commitment device (here we follow the lead of Söderström, 2005).

Inevitably, such stylized story does not do full justice to monetary targeting as practiced by the Bundesbank. Nevertheless, it does, in our view, help to interpret the historical evidence. Specifically, our stylized story suggests one mechanism through which monetary targeting provided a means to anchor inflation and inflation expectations. We derive an interest rate rule corresponding to this set-up and confront it with real-time data. We find that the interest rate rule implied by our model of monetary targeting captures the Bundesbank's monetary policy actions well. We compare the policy pursued in Germany with those conducted by the FED and the Bank of England.

\footnotetext{
${ }^{1}$ These models have also been actively used in policy-making institutions. Prominent examples are the ECB, the Board of Governors and the IMF. Relevant references are Smets and Wouters (2003, 2007), Coenen et al. (2008), Christiano et al. (2008) Erceg et al. (2006), Edge, et al. (2007) and Bayoumi et al. (2004).
} 
The paper is organized as follows. In section 2 we provide an overview of the relative performance of German monetary policy as compared with other industrialized countries. In section 3 we briefly describe institutions and history of monetary policy in Germany in the relevant period. We elucidate the concept of "pragmatic monetarism" and clarify the crucial role of the explicit derivation of the monetary target. In section 4 we introduce a simple macroeconomic framework based on the standard new Keynesian model. We derive a role for monetary targeting as a commitment devise. We obtain the instrument rule implied by our framework. In section 5 we estimate an interest rate rule, inspired by our theoretical analysis, using real time German data and compare the results with estimates for the US and the UK. In section 6 we conclude. 


\section{Brief overview of inflation developments in selected industrial countries in the period 1959-1998}

In the second half of the twentieth century, the German Bundesbank acquired a strong reputation for maintaining lower inflation rates than many other countries could. In this section we will look at the relevant stylized facts and put them into historical context, in particular from a monetary policy perspective. From a global view, the second half of the $20^{\text {th }}$ century was marked by three periods: by the system of Bretton Woods which lasted until 1973 , to be followed by the period of the "Great Inflation" until the end of the 1970s and subsequently by the period of "Great Moderation" from the early to mid 1980s onwards.

\subsection{Rise and fall of the Bretton Woods regime}

The first part of the post-world war II period was marked by the Bretton Woods International Monetary Regime. The beginning of this stage is characterized by the transition to a regime of convertibility, for current account transactions, by most Western European Countries, in December 1958. It involved the fixing of a par value for each currency in terms of gold. The framers of the system intended to reconcile the positive aspects of the classical gold standard (for example exchange rate stability, intense international trade) with autonomous national macroeconomic policies. The idea was that currency convertibility would be expected only for current account transactions (capital controls were accepted) and that exchange rates would be fixed but adjustable (in the face of fundamental disequilibria). According to Garber (1993): "The collapse of the Bretton Woods system of fixed exchange rates was one of the most accurately and generally predicted of major economic events." The intuition is that there are intrinsic elements of internal tension in any gold exchange standard. Bordo (1993) categorizes the problems under the heading adjustment, liquidity and confidence. One aspect is known as the Triffin (1960) dilemma. The system relied on the convertibility of the US dollar into gold. On the other hand it required the availability of US dollars as liquidity. The latter required US balance of payment deficits, thereby undermining (the former) convertibility of the US dollar. The most symbolic moment was, perhaps, the suspension of the convertibility of the dollar into gold, in August 1971. The system then collapsed completely into a system of generalized floating in 1973. With the collapse of the last operational link to gold, the age of a commodity standard was over. 
According to a very well-known folk theorem of international monetary economics, fixed exchange rates, freedom of movement of financial capital and autonomous monetary policy constitute an impossible trinity. As mentioned above, the Bretton Woods regime allowed for capital controls. Nevertheless, over time, in the context of full convertibility for current account transactions, the effectiveness of capital controls was gradually diminishing. The Bundesbank was vividly aware of the constraint that participation in the Bretton Woods systems imposed on its ability to pursue domestic price stability. During the period 1959-1973 the DM was re-valued three times against the US dollar $\left(1961,1969\right.$ and 1971) ${ }^{2}$.

\subsection{The stylized facts}

In the period 1960-1998, German inflation, measured in accordance with the Consumer Price Index, was, on average, 3.1 per cent per year (with a standard deviation of 1.8 percentage points). During this period German inflation was the lowest and most stable, as recorded internationally (see Table 2.1, which reports the average numbers of key macroeconomic variables for the G7 countries and Switzerland over that period). Only Switzerland came close with an average inflation rate of 3.3 per cent (and a standard deviation of 2.3 percentage points). These results compare with the US that recorded an inflation rate of 4.4 per cent, on average per year, with a standard deviation of 2.9 percentage points. Across the G7 countries inflation was highest and most volatile in Italy with, respectively, 7.4 per cent and 5.4 percentage points for annual inflation and for its standard deviation. After the full period the Deutsche Mark (DM) had retained about 30 per cent of its original value, compared with less than 20 per cent for the US dollar, the Canadian dollar and the Japanese Yen, about 13 per cent for the French Franc, about 8.5 per cent for the Pound Sterling and only about 6 per cent for the Italian Lira.

It is interesting (and instructive) to recall that during the 1960s, in the context of the Bretton Woods system, inflation was actually slightly higher in Germany than in the US. Specifically, the ten-year average was 2.4 per cent in Germany, while it was 2.3 per cent in the US (Canada was very close with an inflation rate of 2.5 per cent). Nevertheless, in the UK, France, Italy inflation was on average above 3 per cent and in Japan above 5 per cent. However, using an average for the sixties can be misleading. In the last years of the sixties, the rise in consumer

\footnotetext{
${ }^{2}$ There were also short episodes of floating.
} 
prices was accelerating in the US with inflation at 2.8 per cent in 1967, 4.2 per cent in 1968, 5.4 per cent in 1969 and 5.9 per cent in 1970. The corresponding numbers for Germany were 1.6, 1.6, 1.9 and 3.4 per cent.

The differences between the inflation rates in Germany and the other G7 countries were most marked at the start of the period of floating exchange rates. In fact, in the period 1974-1982 prices increased by 46 per cent in Germany (with an average annual rate of 4.8 per cent). In the same period of eight years, prices almost doubled in the US (with an annual average inflation rate of 9 per cent). The differences persisted in the subsequent disinflation. In the longer period 1974-1989 (the year of the fall of the Berlin Wall), prices increased by 72 per cent in Germany (with an average annual rate of 3.5 per cent) and by 181 per cent in the US (corresponding to an annual average rate of 6.7 per cent). It is also worth noting that only in Germany and Switzerland did inflation peak at single-digit levels in the 1970s and the 1980s. Italy and the UK recorded two-digit ten-year averages in the 1970s. Italy did so in the 1980s as well (see Fig. 2.1). Table 2.1 shows that the same comparison also applies to the volatility of inflation ${ }^{3}$.

Germany's favorable performance applies also to the behavior of nominal interest rates. In Figure 2.2 we show the averages of short-term ( 3 months) and long-term (10 years) interest rates during the 1970s. Evidently, German interest rates were then at the lower end of the interest-rate spectrum.

Regarding the behavior of real variables, however, it is worth noting that they did not diverge significantly among industrialized countries during the same period. Figure 2.3 shows that in the 1970 s, there was no obvious trade-off between real GDP growth rates and inflation across countries.

\subsection{Explanations of the Great Inflation}

To avoid the accusation of omitting important facts, let us refer briefly to the most widespread explanation of the Great Inflation. According to Bruno and Sachs (1985), the key factor

\footnotetext{
${ }^{3}$ With some qualification for the case of Canada.
} 
behind the acceleration of prices were the oil price shocks ${ }^{4}$. Bruno and Sachs (1985) state (page 7): "A clear and central villain of the piece is the historically unprecedented rise in commodity prices (mainly food and oil) in 1973-74 and again in 1979-80 that not coincidentally accompanied the two great bursts of stagflation." The traditional explanation emphasizes supply shocks and the subsequent demand response. Supply shocks play the role of the initial exogenous impulse followed by endogenous adjustment of the private sector and policy authorities. Barsky and Kilian $(2002,2004)$ offer an alternative reading of the facts. According to their account, oil prices, and other commodity prices, should be seen as responding to global supply and demand factors. Specifically, the authors account for the increase in oil prices in 1973 as a delayed adjustment to consistent demand pressure persisting since the late 1960s. The adjustment was delayed because during the 1960s oil prices were regulated through long term contracts between oil producers and oil companies. In a situation of clear excess demand at the going price, conditions were ripe for OPEC to renege on its contractual agreements with oil companies leading to much higher oil prices. From such a viewpoint, it seems plausible that broad upward trends in commodity prices, the collapse of Bretton Woods and the collapse of the oil market regime were all driven by excess demand growth in the late 1960s and the early 1970s. This would be compatible, following Barsky and Kilian, with a broad monetary account of the Great Inflation. Despite our obvious sympathy for such an account, investigating it is beyond the scope of this paper.

Still, the fact that inflation in the US and other member countries of the Bretton Woods System accelerated well before the first hike in oil prices supports the hypothesis that demand shocks (among them, increases in government spending) in conjunction with accommodative monetary policy prepared the ground for the inflationary surges of the 1970s. Furthermore, Figure 2.1 suggests that it was the response to the oil price shocks of the 1970s that made most of the difference. The Bundesbank did not manage to avoid price acceleration completely (CPI inflation averaged 4.8 per cent during the 1970s) but performed much better than most of all other industrialized countries. ${ }^{5}$ The remainder of the paper is thus devoted to the question: how did Germany manage to opt out of the Great Inflation?

\footnotetext{
${ }^{4}$ Other related references would be Samuelson (1974), Gordon (1975), Blinder (1979), Darby (1982) and Hamilton (1983).

${ }^{5}$ The differences would be even more striking if one would consider a wider sample of industrialized countries (see, for example, Frenkel and Goldstein, 1999, who consider 23 countries).
} 


\section{Sound money and price stability in Germany}

\subsection{The legacy of the Bundesbank and stability-oriented monetary policy}

On 31 December 1998, together with all national central banks joining European Monetary Union, the Deutsche Bundesbank ended its life as a central bank responsible for conducting monetary policy for its currency. Combining this period with the term of its predecessor, the Bank deutscher Länder, the overall period coincides with the existence of the D-Mark. ${ }^{6}$

The D-Mark developed - together with the Swiss Franc - into the most stable currency in the world after 1945, and the Bundesbank achieved a reputation as a model of a solid, successful central bank. This left a legacy reaching beyond its existence as a central bank responsible for a national currency. The statute of the European Central Bank, enshrined in the Maastricht Treaty, reflects this fact very well. But it is also fair to say that, in addition, the Bundesbank's track record influenced the world of central banking on a global scale.

This world-wide attention was heavily influenced by the fact that Germany (again together with Switzerland) avoided the "Great Inflation" of the 1970s. What explains such a superior ability to approach price stability? In this sub-section, we will examine the historical, cultural and institutional background. In the next sub-section, we will develop a theoretical model which formalizes the Bundesbank's strategy and in section 5, we will characterize quantitatively the conduct of monetary policy by the Bundesbank.

To explain Germany's post Second World War monetary history one has to go back to 1948 and even beyond. The institutional foundation was laid in 1948 by law of the allies - (West) Germany did not yet exist as a state - which gave the Bank deutscher Länder independence from any political authorities. ${ }^{7}$ When a few months later the D-Mark was introduced, this institution was entrusted preserving the stability of the new currency.

\footnotetext{
${ }^{6}$ To be precise: The Bank deutscher Länder was established on 1 March 1948. The D-Mark became the currency of (then) West Germany on 21 June 1948. The Bundesbank replaced its predecessor on 26 July 1957.

${ }^{7}$ De jure the Allied Bank Commission could interfere, but never made any use of this prerogative. See Buchheim (1999).
} 
The currency reform in cooperation with the simultaneous economic reforms of Ludwig Ehrhard laid the foundations of (West) Germany's economic success, the so-called "Wirtschaftswunder" (economic miracle).

As a consequence, most Germans for the first time in their life enjoyed a stable currency. This experience had a deep impact on the mind of the German people. The Mark, initially (1873) created as a currency based on gold had ended its existence in the hyperinflation of 1923 which destroyed Germany's civil society. ${ }^{8}$ The successor of the Mark, the Reichsmark, created in 1924 ended its short life with the currency reform of 1948. People had again lost most of their wealth invested in nominal assets. No wonder that a strong aversion against inflation and a desire for monetary stability became deeply entrenched in the mind of the German people! ${ }^{9}$ It became so entrenched in Germans' expectations, habits and customs that it deserved the special expression "stability culture". It is interesting to stress the virtuous interaction between Germany's stability culture and the independence of the Bundesbank.

A particular historical episode illustrates it emphatically. The German Constitution of 1949 required the Government to prepare the Deutsche Bundesbank law. It was no secret that then chancellor Konrad Adenauer was not a friend of an independent central bank. However, his clash with the central bank in May 1956 when he criticised in public the increase of the discount rate (from 4.5 to 5.5 percent) - “...the guillotine will hit ordinary citizens...” had already demonstrated to what extend the media and the public, at large, were behind the independence from political interference of the central bank. As a consequence, he lost the battle against the minister of the economy Ludwig Erhard. In the end, the Bundesbank law of 1957 in section 12 stated explicitly that: "In exercising the powers conferred on it by this Act, [the Bundesbank] is independent of instructions from the Federal Government." Together with the mandate in section 3 of "safeguarding the currency" the Bundesbank Act established the institutional fundament for a stability oriented monetary policy. ${ }^{10}$

\footnotetext{
${ }^{8}$ Stefan Zweig (1970), a writer, claims in his memoirs of that time that the experience of this total loss of the value of the currency more than anything else made Germans "ripe for Hitler".

${ }^{9}$ It was interesting to see that in the days before the Berlin Wall fell demonstrators in the streets of Leipzig carried posters saying: "If the D-Mark is not coming to us we will come to the D-Mark". So this desire for stability had also affected the mind of East Germans.

${ }^{10}$ It is interesting to note that "safeguarding the currency" initially referred to the "domestic" as well as the "external" value (i.e. the exchange rate) of the currency. Over time the Bundesbank succeeded in obtaining general acceptance of its interpretation of safeguarding the purchasing power of the currency.
} 
Notwithstanding the fact that this law could have been changed at any time by a simple majority of the legislative and insofar seemed to be based on shaky legal ground, the reputation of the Bundesbank became such that there was never any serious initiative to change the law. The status of the Bundesbank and the support for its stability oriented monetary policy was firmly grounded on (and, in turn, reinforced) the "stability culture" (see Issing 1993).

At the time of the ratification of the Bundesbank Act there were not only hardly any independent central banks in the world, it is even difficult to find any serious discussion in the literature on the issue of an appropriate institutional arrangement for a central bank. Interest in this topic was mainly triggered by the experience of the "Great Inflation" in the 1970s and the more and more obvious failures of monetary policy in many countries. First publications discussed credibility issues (Barro and Gordon) and the time inconsistency problem (Kydland and Prescott). The outcome of monetary policy depending on the statute - here the degree of independence of the central bank - commanded broader attention only in the 1990s, with a paper by Alesina and Summers. ${ }^{11}$

Since, the number of publications on central bank independence has exploded, discussing all aspects from defining independence, measuring its degree to designing optimal contracts for central bankers. Is it wrong to say that the good performance of the Bundesbank not least in the 1970s has contributed to, if not triggered, this branch of research?

This interest in the topic and the result by more and more research papers has also supported the claim to give independence to the new central bank which still had to be founded, the European Central Bank. One should not forget that some of the countries signing the Maastricht Treaty at that time (1992) still had not given independence to their own national central banks. Since then "independence" of the central bank has become a model also on a global scale.

In a nutshell the message stemming from experience and theory is: Institutions matter! The outcome of monetary policy is heavily dependent on the institutional design of the central bank.

\footnotetext{
${ }^{11}$ See Alesina and Summers (1990). An early paper by Bade and Parkin (1980) was widely ignored and not even published.
} 
Another aspect of great importance pertained the exchange rate regime (see previous section for a brief reference to the Bretton Woods system and some selected references to the relevant literature). For many years, the Bundesbank was in favour of a fixed exchange rate of the DMark against the US-Dollar. It even argued against the appreciation of the D-Mark in 1961. The law of the "uneasy triangle" had been more or less forgotten (Issing 2006). However, towards the end of the 1960s, it became increasingly apparent that the fixed exchange rate was a constraint for conducting a monetary policy geared towards a domestic goal, namely price stability. (Richter 1999; von Hagen 1999). In a regime of a fixed exchange rate and free capital flows, money growth becomes endogenous and any attempt to withstand the import of inflation is finally self-defeating.

The Bundesbank experienced a period of excessive money growth driven by interventions buying US-Dollars. In the late 1960s and early 1970s, the external component of money creation was sometimes even higher than the growth of the monetary base, implying that the internal contribution of money creation was negative. The consequences of this constellation for the institutional design of monetary policy were far-reaching: The Bundesbank, notwithstanding its independence from political interference, equipped with all the necessary instruments, was powerless with respect to pursuing a domestic goal since the exchange rate was fixed and capital flowed freely across borders. This fundamentally changed when in March 1973 Germany let its currency float against the US-Dollar. The Bundesbank being relieved from its obligation to intervene in the exchange market could now consider conducting a monetary policy to safeguard the internal stability of its money, i.e. maintaining price stability.

The Bundesbank declared the fight against inflation to be the principal goal of its monetary policy $^{12}$ and, in line with this, had already started to slow down inflation (which had peaked at almost 8 per cent in mid-1973) when in October 1973, the first oil crisis broke out. The rise in oil prices thwarted the efforts of the Bundesbank while real output started to decline at the same time. Being confronted with such a situation, the Bundesbank attempted to keep monetary expansion within strict limits in order to avoid possible spill-over effects into the wage and price-setting. In doing so, it did, however, not commit itself to any clear strategy and quantification. ${ }^{13}$ Instead, the Bundesbank mainly tried to influence the behaviour of

\footnotetext{
12 See Deutsche Bundesbank (1974), Annual Report, p. 45.

${ }^{13}$ In fact, the Bundesbank tried to ensure that "monetary expansion was not too great but not to small either". See Deutsche Bundesbank (1974), Annual Report, especially p. 17.
} 
market participants by means of "moral suasion". However, the social partners more or less ignored the signals given by the Bundesbank and agreed on high increases in nominal wages in 1974 trying to compensate for the loss in real disposable income. As a consequence unemployment increased and inflation went up.

Against this experience, the idea of adopting a formal quantitative target for money growth which would provide a nominal anchor for inflation and inflation expectations rapidly gained ground. As it happened this period coincided with the "monetarist counterrevolution." The leading monetarists Milton Friedman, Karl Brunner and Alan Meltzer claimed that central banks should abstain from any attempt to fine-tune the economy and should instead follow a strategy of monetary targeting. (A floating exchange rate was a necessary condition for controlling the money supply.) These ideas in principle found positive reactions in Germany (Richter 1999; von Hagen 1999). The Bundesbank discussed this approach internally and with leading proponents. Helmut Schlesinger, member of the Executive Board and chief economist, had an intensive exchange of views not least when participating in the intellectually influential Konstanz Seminar founded by Karl Brunner in 1970. ${ }^{14}$ The rejection of fine-tuning and the medium-term orientation of monetary policy implied by monetary targeting was strongly supported also by the German Sachverständigenrat (1974).

However, in spite of the Bundesbank being the first central bank in the world to adopt a monetary target (for the year 1975), the honeymoon with leading monetarists came soon to an end. This process started already when the Bundesbank declared its move to the new strategy "an experiment", stressed that it would not (and, in the short run, could not) control the monetary base, and over many years missed its monetary target.

The Bundesbank interpreted its approach as a kind of "pragmatic monetarism" and kept to this strategy until 1998 (see Baltensperger 1999, Issing 2005, and also Neumann, 1997, 1999). Not surprisingly, this attitude was heavily criticised especially by Karl Brunner (1983). However, in its monetary policy practice, the strategy served the Bundesbank well in defending the stability of its currency - if not in absolute terms it did at least (together with the Swiss National Bank) substantially better than most other central banks.

\footnotetext{
${ }^{14}$ See Fratianni and von Hagen (2001). The authors give a comprehensive survey on subjects discussed and persons attending. The seminar still continues and was chaired for many years by the leading German monetarist Manfred Neumann.
} 


\subsection{The conduct of policy under monetary targeting $^{15}$}

\section{a) Derivation of the money growth target}

The choice of a monetary target in 1974 undoubtedly signalled a fundamental regime shift. Not only was it a clear break with the past but also a decision to discard alternative approaches to monetary policy. ${ }^{16}$ There were two main arguments in favour of providing a quantified guidepost for the future rate of monetary expansion. First and foremost was the intention of controlling inflation through the control of monetary expansion. Second, the Bundesbank tried to provide guidance to agents' (especially wage bargainers') expectations through the announcement of a quantified objective for monetary growth. ${ }^{17}$ Therefore, with its new strategy, the Bundesbank clearly signalled its responsibility for the control of inflation. At the same time, the Bundesbank expressed its view, that while monetary policy by maintaining price stability in the longer run would exert a positive impact on economic growth, the fostering of the economy's growth potential should be considered a task of fiscal and structural policies, while employment was a responsibility of the social partners conducting wage negotiations.

Although the formulation of the new strategy was heavily influenced by the ideas of the leading monetarists, the implementation of monetary targeting in Germany deviated from the theoretical blueprint in a number of ways. One important difference was that Bundesbank did not formulate its targets in terms of the monetary base, but in terms of a broadly defined monetary aggregate, the central bank money stock (defined as currency in circulation plus the required minimum reserves on domestic deposits calculated at constant reserve ratios with base January 1974). ${ }^{18}$ Secondly, the Bundesbank did not attempt to control the money stock directly, but followed an indirect approach of influencing money demand by varying key money market rates and bank reserves (two-stage implementation procedure). Thirdly, the Bundesbank made it clear from the beginning that it could not and would not promise to

\footnotetext{
${ }^{15}$ Parts of the following section are taken from Issing (2005).

${ }^{16}$ It must be recognized that the start of monetary targeting was characterized by a high degree of uncertainty. After all, Germany had just come out of the Bretton Woods "adjustable peg" system in which many topics were seen as irrelevant.

${ }^{17}$ See Schlesinger (1983) on this issue.

${ }^{18}$ The ratios were $16.6 \%$ for sight deposits, $12.4 \%$ for time deposits and $8.1 \%$ for savings deposits. After the mid-eighties, the heavy weight on currency increasingly proved to be a disadvantage, and when setting the target for 1988, the Bundesbank switched to the money stock M3. See Deutsche Bundesbank (1995), p. 81f.
} 
reach the monetary target with any degree of precision. Accordingly, in this period, the new regime of monetary targeting was in many respects an experiment.

From the outset, the Bundesbank recognized the importance of adopting a simple, transparent and at the same time comprehensible method for the derivation of the annual monetary targets. ${ }^{19}$ The analytical background for the derivation formula was provided by the quantity theory of money. Starting from the quantity identity, one gets that average money growth, $\Delta \bar{m}$, and average inflation, $\Delta \bar{p}$, will fulfil the identity:

$$
\Delta \bar{m}_{t}+\Delta \bar{v}_{t} \equiv \Delta \bar{p}_{t}+\Delta \bar{y}_{t}
$$

where $p, m, y$ and $v$ are the (logs of the) price level, the money stock, real income and the income velocity of money, respectively, and the bars denote long-run average values. Taking the velocity trend and the long-run average rate of real output growth to be exogenous, it follows from (3.1) that trend inflation can be pinned down by controlling the trend rate of money growth:

$$
\Delta \bar{p}_{t}=\Delta \bar{m}_{t}-\Delta \bar{y}_{t}+\Delta \bar{v}_{t}
$$

Based on this reasoning, the Bundesbank derived the target for average money growth in year $t, \Delta m_{t}^{*}$, from the sum of the (maximum) rise in prices it was willing to tolerate, $\Delta p_{t}^{*}$, the predicted growth in potential output, $E_{t-1} \Delta y_{t}^{*}$, and the expected trend rate of change in velocity, $E_{t-1} \Delta v_{t}^{*}$ :

$$
\Delta m_{t}^{*}=\Delta p_{t}^{*}+E_{t-1}\left(\Delta y_{t}^{*}\right)-E_{t-1}\left(\Delta v_{t}^{*}\right)
$$

where the deltas now represent year-on-year changes, and $E_{t-1}$ denotes expectations at the end of year $t-1$. The target rate for average (year-on-year) money growth was then translated into a target rate for money growth in the course of the year (see Table 3.2 and Neumann, 1997, 180ff).

The approach reflected the insight that monetary growth consistent with this derivation would create the appropriate conditions for real growth in line with price stability. While these basic relationships were uncontested over medium to longer-term horizons, the Bundesbank was

\footnotetext{
${ }^{19}$ See also Issing (1997) for the following considerations.
} 
fully aware of the fact that they might not strictly apply over the shorter term. On a month-tomonth or quarter-to-quarter basis and even beyond, the basic relationship between the money stock and the overall domestic price level was often obscured by a variety of other factors. Any attempt to strictly tie money growth to its desired path in the short-term might have led to disturbing volatility in interest and exchange rates, thus imposing unnecessary adjustment costs on the economy. Accordingly, the Bundesbank repeatedly pointed to the medium-term nature of its strategy and explained that it was prepared to tolerate short-term deviations from the target path if that seemed advisable or acceptable in terms of the overriding goal of price stability.

\section{b) From 1975 to 1978 - the learning phase}

First experiences with monetary targets were not particularly encouraging. Between 1975 and 1978, the quantitative targets were clearly (and in 1978 considerably) overshot (see Table 3.2). The sharp increase in interest rates which had taken placed immediately after the end of the Bretton Woods System was almost completely reversed in 1974/75 and real short-term interest rates were kept rather low until the beginning of 1979 (see Figure 4.2a). Clarida and Gertler (1997) interpret this as evidence "that the Bundesbank's commitment to fight inflation waned somewhat during the period between the two major oil shocks". Von Hagen (1999) argues that following the first oil price shock, short-term employment-related goals gained prominence. In the Bundesbank's own reading, the loosening was mainly motivated by two considerations which, in hindsight, turned out to be partly based on misjudgments. First, policymakers apparently overestimated the extent to which the currency appreciation would dampen real activity and inflation. The second misjudgment concerned the depth of the 1975 recession, which in hindsight, turned out to have been greatly overestimated (see Gerberding et al., 2004). ${ }^{20}$

Nevertheless, the Bundesbank was able to slow down inflation from the high levels before to $2.7 \%$ in 1978. During this period the Bundesbank gained valuable insights into the new regime and introduced a number of technical modifications (see Table 3.2). These experiences helped the Bundesbank to enhance the monetary targeting concept from its experimental stage into a fully-fledged strategy. As a consequence, at the end of 1978, the potential-oriented monetary targeting strategy had been established and had proven its value. Therefore, the

\footnotetext{
${ }^{20}$ See Bundesbank, AR 1975 and 1976.
} 
Bundesbank was well prepared when the German economy entered especially troubled waters.

\section{c) From 1979 to 1985 - the strategy bears fruit}

The economic situation in 1978 was broadly seen as rather comfortable. German real GDP had grown by around 3 per cent, accompanied by high levels of employment growth and falling unemployment. The situation was, however, less positive in terms of monetary growth and inflation. Monetary growth had overshot its target and there were signs of acceleration in the rate of inflation, which in 1978 stood, on average, at $2.7 \%$. Furthermore, in 1979, the sharp increase in oil prices associated with the second oil price shock hit the German economy. The resulting massive increase in import prices, especially energy prices, augmented by a weakening of the exchange rate, brought about a turnaround in Germany's current account position, leading to a current account deficit in 1979 for the first time in many years.

At the same time, government fiscal policy was clearly expansionary. Thus, fiscal policy rendered the central bank's task even more difficult. Moreover, the European Monetary System (EMS), an exchange rate regime defining the exchange rates of participating currencies in terms of central rates against the ECU, had begun rather quietly in March 1979, but subsequently faced tensions and the need to adjust parities from as early as September 1979.

It was obvious from the beginning that the direct effect of the oil price shock on consumer prices could not be prevented by monetary policy. At the same time, the Bundesbank had carefully analysed the lessons of the first oil price shock. Against this experience, in 1979 the Governing Council of the Bundesbank was well aware of the threat that the oil price increase could translate again into sustained increases in inflation brought about by second-round effects in wage and price-setting. ${ }^{21}$ In responding to these challenges, the Bundesbank took decisive action. The discount rate was increased in steps from 3 per cent at the start of 1979 to reach 7.5 per cent in May 1980. In parallel, the Lombard rate was increased from its initial level of 3.5 per cent to 9.5 per cent in May 1980, and in February 1981 - as a special Lombard

\footnotetext{
${ }^{21}$ See Schlesinger (1980) on this point.
} 
- to as much as 12 per cent, the normal Lombard window being closed.22 By subsequently reducing the monetary targets from 1979 onwards, the Bundesbank sent out a clear signal for restoring price stability.

Not until the second half of 1981 did the growth rates for the monetary base begin to come down. Towards the end of 1981, there were increasingly clear signs of an easing of price and wage pressures. The D-Mark regained confidence in the foreign exchange markets and strengthened again, not only within the EMS but also in relation to the US-Dollar. The external adjustment process was promoted through a slowdown in domestic demand and the current account position improved noticeably. Furthermore, through the "monetary warning", the government became aware of the unsustainability of its deficit policy. From then on, budget consolidation was increasingly recognized as being an urgent task.

The subsequent years 1982-85 can be regarded as a phase of monetary relaxation and normalisation. The Bundesbank's monetary policy was focused on bringing down inflation and restoring the stability of the currency, and it proved able to realise this aim throughout the period. The benchmark figure for the tolerated rate of inflation (which, until 1984, was termed the "unavoidable" rate of price increase) was gradually reduced from $3 \frac{1 / 2}{2} \%$ in 1982 to $2 \%$ in 1985. At the same time, actual inflation fell steadily from an annual average rate of $5.2 \%$ in 1982 to $2.0 \%$ in 1985 . When price stability was virtually reached in the middle of the $1980 \mathrm{~s}$, the Bundesbank changed over from the concept of an "unavoidable" rate of inflation to a medium-term price norm or price assumption of no more than $2 \%$ (see Table 3.1 ).

\section{d) The last test - German reunification}

Given the stability-oriented monetary policy strategy and the developments described above it is far from surprising that, at the end of the eighties, the Bundesbank was one of the most respected central banks in the world. At the beginning of the $1990 \mathrm{~s}$, it was about to face an important historical test, in the form of German re-unification.

The D-mark was introduced in the eastern Länder on 1 June 1990. Curiously the introduction of the currency preceded political unification (3 October 1990). The extension of the territorial scope of monetary policy clearly led to a significant increase in uncertainty. Specifically, the operation entailed an increase in money supply of the order of $15 \%$ of West

\footnotetext{
${ }^{22}$ See Baltensperger (1999) for a more detailed description of this period, the monetary targets and their realisations.
} 
German money stock. This number compared with about $10 \%$, which would have been appropriate on the basis of estimates of the relative size of the former GDR's GDP at market prices. Moreover, there were additional factors challenging the conduct of the Bundesbank's stability-oriented policy. In fact, German re-unification led to a massive expansion of aggregate expenditure in Germany, including sizeable general government deficits. As a consequence inflation rose quickly, with price increases (in West Germany) exceeding 4\% in the second half of 1991.

How could the Bundesbank under these circumstances maintain price stability over the medium term? How could it preserve credibility?

The Bundesbank decided to stick to its tried and tested framework, including the normative rate of $2 \%$ for inflation. This option implied that the Bundesbank was, for a short time, prepared to accept monetary expansion above the announced target. Again, the money growth targets proved to be highly beneficial in terms of anchoring inflation expectations, even though it was not easy to derive an adequate money growth target for reunited Germany (see Issing et al., 2005, p. 3f). The Bundesbank abided by its well-proven strategy right up to the beginning of EMU in January 1999. While some technical features of the strategy (e.g. the exact definition of the target variable) were changed over time, its major elements - the explicit derivation of the annual money growth targets from medium-term macro-economic benchmark figures, the flexible implementation which included temporary departures from the medium-term rule, and the two-stage implementation procedure- - stayed intact. In this respect, the Bundesbank's approach certainly stands out by reason of its consistency and remarkable continuity.

\section{e) Lessons}

What are the lessons that can be drawn? Why was Germany better able to counter the inflationary shocks of the 1970s than most other countries? Several key aspects emerge from this brief review of German monetary policy after the end of the Bretton Woods System. To begin with, the Bundesbank was the first central bank to announce a monetary target and thus to undertake a strategy of commitment, transparently communicated to the public. ${ }^{23}$ Moreover, when announcing the money growth targets, the Bundesbank disclosed the most important guiding principles behind its decisions, such as the maximum rise in prices that

\footnotetext{
${ }^{23}$ See Issing, 1992, p. 291.
} 
would be tolerated by the central bank and its estimate of potential output growth. By doing so, the Bundesbank fostered transparency and provided an anchor for medium-term inflation expectations. In retrospect, against the background of the more recent debate about the merits of an intensive communication policy, these elements of the Bundesbank's strategy appear very modern indeed.

After the initial years of experimentation, the strategy had proven its value in the baptism of fire of 1979 and the early 1980s. In doing so, it had managed to establish credibility which, in turn, had started to set in motion a virtuous circle. Still, one may well ask - and indeed, it has often been asked - how the Bundesbank was able to get away with its practice of deviating time and again from the announced targets while at the same time preserving its reputation as a bulwark of monetary stability. ${ }^{24}$ After all, even if one excludes the years 1975-78, the targets were missed seven out of 20 times (see Figure 3.1).

As explained by Issing (1997, p. 71f), the target misses were rarely of a completely involuntary nature, but mostly constituted deliberate monetary policy decisions. Yet, it was exactly in those situations that the monetary targets had an especially valuable disciplining effect because once a target was missed the decision makers were put under pressure to justify the outcome in terms of the ultimate aim of safeguarding the currency. Similarly, Schlesinger (2002) argues that the targets imposed discipline on the decision makers by forcing them to explain their decisions and to persuade the public that failures to meet the intermediate target did not jeopardise the final goal of policy. Finally, according to Neumann (2006, p. 14), "the Bundesbank was the first central bank that provided the public (or at least, an elite audience), with an intelligible numerical framework that facilitated the evaluation of its policy course from the outside". Viewed from this perspective, the money growth targets represented a movement away from purely discretionary policy towards a more rule-based behaviour. The Bundesbank itself has sometimes designated its strategy as constrained or disciplined discretion, Neumann (1997) talks of "rule-based discretion".

\footnotetext{
${ }^{24}$ See Neumann, 2006, p. 14.
} 


\section{Monetary targeting as a commitment device}

As explained in the previous section, the Bundesbank did not attempt to control the money stock directly, but followed an indirect management procedure which worked via influencing conditions in the money market. Hence, on a basic level, the Bundesbank's approach may be described as setting the short-tem interest rate so as to achieve the rate of money growth that was viewed as consistent with the attainment of the final goal, price stability. In this section, we present a model which formalises this approach and enables us to compare the implied interest rate rule with other interest rate rules proposed in the academic literature (such as the Taylor rule and its many variants).

Taylor (1999) and more recently, Orphanides (2003) and Kilponen and Leitemo (2008) have discussed the implications of targeting money growth for a central bank which sets the shortterm interest rate. Although we know from the previous section that the Bundesbank's practice of monetary targeting differed from the monetarist blueprint in a number of ways, it is still instructive to consider the simple case of a "pure" or "strict" money growth rule first. Under strict money growth targeting, the central bank is required to find the short-term interest rate, $i_{t}$, which sets the growth rate of money equal to the pre-specified target:

$$
\Delta m_{t}=\Delta m_{t}^{*}
$$

subject to a money demand relation that relates real money holdings to output and the interest rate: ${ }^{25}$

$$
\left(m_{t}-p_{t}\right)=\eta_{y} \cdot y_{t}-\eta_{i} \cdot i_{t}+\varepsilon_{t}^{m d}
$$

where $\varepsilon_{t}^{m d}$ captures short-run dynamics and shocks to money demand. Taking first differences, the growth rate of money is related to the inflation rate, the change in the nominal interest rate and the growth rate of output through

$$
\Delta m_{t}=\pi_{t}+\eta_{y} \Delta y_{t}-\eta_{i} \Delta i_{t}+\Delta \varepsilon_{t}^{m d} .
$$

Given the money demand relation (4.2), equilibrium velocity can be written as

\footnotetext{
${ }^{25}$ Such a money demand equation can be derived from the optimization problem of a household who values money holdings in its utility function that is separable in real balances and consumption goods, see Woodford (2003).
} 


$$
v_{t}^{*}=-\left(\left(m_{t}-p_{t}\right)^{*}-y_{t}^{*}\right) \text {, where }
$$

$$
\begin{aligned}
& \left(m_{t}-p_{t}\right)^{*}-y_{t}^{*}=\left(\eta_{y}-1\right) y_{t}^{*}+\eta_{i} \cdot i_{t}^{*}+\varepsilon_{t}^{v^{*}} \\
= & v_{t}^{*}=\left(1-\eta_{y}\right) y_{t}^{*}-\eta_{i} \cdot i_{t}^{*}-\varepsilon_{t}^{v^{*}}
\end{aligned}
$$

and equilibrium changes in velocity

$$
\Delta v_{t}^{*}=\left(1-\eta_{y}\right) \Delta y_{t}^{*}-\eta_{i} \cdot \Delta i_{t}^{*}-\Delta \varepsilon_{t}^{v^{*}}
$$

are represented by a function of potential output growth and of changes in the steady-steady level of the nominal interest rate (if there are any). We define the velocity shock $\varepsilon_{t}^{v^{*}}$ as a shock to equilibrium money demand. We interpret $\varepsilon_{t}^{v^{*}}$ as a portfolio shock that can be observed by the central bank due to its institutional knowledge.

As discussed in the previous section, a central bank with the objective of controlling long-run average inflation will set the money growth target equal to the "acceptable" rate of inflation, $\pi_{t}^{*}$, adjusted for the predicted growth rate of potential output and the expected trend rate of change in velocity (which is exactly what the Bundesbank did):

$$
\Delta m_{t}{ }^{*}=\pi_{t}^{*}+E_{t} \Delta y_{t}^{*}-E_{t} \Delta v_{t}^{*}
$$

Note that in contrast to Eq (3.3), we now assume that the money growth targets are based on current-period expectations of $\Delta y_{t}^{*}$ and $\Delta v_{t}^{*}$, which presupposes that the money growth targets are regularly updated to take account of revisions in the estimates of potential output growth and the trend change in velocity. ${ }^{26}$ From (4.3a) the formula for the money growth target can be reformulated as:

$$
\Delta m_{t}^{*}=\pi_{t}^{*}+\eta_{y} E_{t} \Delta y_{t}^{*}+\Delta \varepsilon_{t}^{v^{*}}
$$

where we abstract from changes in the nominal equilibrium interest rate (as the Bundesbank did). ${ }^{27}$

Combining (4.2a) and (4.4a), the deviation of money growth from target can now be expressed as:

\footnotetext{
${ }^{26}$ As regards the Bundesbank, the fact that the targets were usually formulated as a corridor of 2 or 3 percentage points (see Table 3.2) provided flexibility for adjustments to changes in the underlying estimates. In addition, there was a regular mid-year review of the targets.
} 


$$
\Delta m_{t}-\Delta m_{t}^{*}=\pi_{t}-\pi_{t}^{*}+\eta_{y}\left(\Delta y_{t}-E_{t} \Delta y_{t}^{*}\right)-\eta_{i} \Delta i_{t}+\left\{\Delta \varepsilon_{t}^{m d}-\Delta \varepsilon_{t}^{v^{*}}\right\}
$$

Using the equality of actual money growth with target (equation (4.1)) entails:

$$
\pi_{t}-\pi_{t}^{*}+\eta_{y}\left(\Delta y_{t}-E_{t} \Delta y_{t}^{*}\right)-\eta_{i} \Delta i_{t}+\left\{\Delta \varepsilon_{t}^{m d}-\Delta \varepsilon_{t}^{v^{*}}\right\}=0
$$

Solving for the nominal interest rate, (4.6) can be transformed into an instrument rule of the form:

$$
i_{t}=i_{t-1}+\frac{1}{\eta_{i}}\left(\pi_{t}-\pi_{t}^{*}\right)+\frac{\eta_{Y}}{\eta_{i}}\left(\Delta y_{t}-E_{t} \Delta y_{t}^{*}\right)+\frac{1}{\eta_{i}}\left\{\Delta \varepsilon_{t}^{m d}-\Delta \varepsilon_{t}^{v^{*}}\right\}
$$

According to (4.7), money growth targeting implies an interest rate reaction to the lagged interest rate, to the deviation of inflation from target, to the deviation of actual output growth from (the central bank's estimate of) potential output growth (which is equivalent to the change in the output gap), and to the difference between the "true" money demand shock $\Delta \varepsilon_{t}^{m d}$, and the portfolio shock observed by the central bank, $\Delta \varepsilon_{t}^{v^{*}}$. As pointed out by Orphanides (2003), the interest rate rule implied by (strict) money growth targeting thus belongs to the class of "natural-growth targeting rules", which do not rely on estimates of the natural rate of interest and output and thus "stay clear of the pitfalls known to plague the natural-rate-gap-based policy approach" (p. 990). Notice, however, that in order to be a meaningful specification, which would be suitable for characterizing the practical implementation of monetary policy, the money demand shocks in (4.7) should have reasonable properties. We will discuss this issue in more detail in Section 5 where we present our empirical results.

However, as discussed in the previous section, the Bundesbank did not adhere to a strict version of the Friedman rule, but instead pursued a strategy of "pragmatic monetarism". Most importantly, the assumption that the central bank hits the money growth target each period which underlies Equation (4.1) is at odds with the Bundesbank's acclaimed medium-term orientation and the fact that it tolerated short-term deviations from target.

According to Issing, one of the fundamental functions of a monetary policy strategy is to confer credibility to the achievement of the final goal of price stability (see, for example,

\footnotetext{
${ }^{27}$ See Gerberding et al. (2007), p. 5f.
} 
Issing et al. 2005). In order to incorporate the key issues of credibility, commitment and reputation in our analysis, we choose a framework which allows us to interpret a monetary target as a commitment device. Specifically, we assume that the Bundesbank council reoptimized the setting of the policy instrument(s) every period, that is, it acted under discretion. However, in our reading, policymakers were aware of the problems associated with discretionary policy and used monetary targeting as a device to get closer to the optimal (but time-inconsistent) commitment solution. In particular, we assume that when setting interest rates, the objective of the Bundesbank council was to minimize deviations of inflation and money growth from target, while also seeking to stabilize output and the interest rate around their respective target values: ${ }^{28}$

$$
E_{0} \sum_{t=0}^{\infty} \beta^{t}\left[\left(\pi_{t}-\pi_{t}^{*}\right)^{2}+\hat{\lambda}_{x} x_{t}^{2}+\hat{\lambda}_{i}\left(i_{t}-i_{t}^{*}\right)^{2}+\hat{\lambda}_{m}\left(\Delta m_{t}-\Delta m_{t}^{*}\right)^{2}\right]
$$

where $\beta$ is the discount factor, $x_{t}$ is the output gap defined as the gap between actual output, $y_{t}$, and potential output, $y_{t}{ }^{*}$, and $\hat{\lambda}_{x}, \hat{\lambda}_{i}$ and $\hat{\lambda}_{m}$ are the relative weights attached to the output, interest rate and money growth terms.

The use of a modified loss function to attenuate the pitfalls associated with discretionary monetary policy was pioneered by Rogoff (1985). More recently, several authors have analysed the properties of monetary policy strategies based on modified loss functions in the context of forward-looking new Keynesian-type models. There are many variants of modified loss functions including, price level targeting (Svensson, 1999, Vestin, 2006, Røisland, 2006 and Gaspar et al., 2007), average inflation targeting (Nessén and Vestin, 2005), interest rate smoothing (Woodford, 1999), nominal income growth targeting (Jensen, 2002) and speed limit targeting (Walsh, 2003).

For our purposes, the most closely related contribution in the literature is Söderström (2005) who analyses the implications of delegating a loss function to the central bank which deviates from society's true loss function by an additional money growth target. As shown by Söderström, this modification can be beneficial for a central bank acting under discretion since the money growth target introduces interest rate inertia and history dependence into

\footnotetext{
${ }^{28}$ In the loss function (4.8), we have abstracted from the complications arising from a gap between the efficient and the natural level of output, but one should keep in mind that with a positive value of $x^{*}$, the optimal discretionary policy suffers from an average inflation bias as well as a stabilisation bias; see Woodford, 2003, p. $469 \mathrm{ff}$.
} 
interest rate decisions, both of which are features of the optimal commitment policy. In Söderström's baseline simulations, a money growth target closes about $80 \%$ of the gap between discretionary policy and the optimal policy under pre-commitment. This result is the more remarkable given the fact that it is obtained in the context of a standard New Keynesian model where money growth is neither useful as an indicator of future inflation nor of output growth, and where money plays no direct role in the transmission mechanism of monetary policy.

Nevertheless, our objective differs from Söderström's. Specifically, we want to derive the interest rate rule characterizing optimal discretionary policy under the modified loss function (4.8). In our reading, this loss function captures some relevant dimensions of the Bundesbank's approach of pragmatic monetarism. Most importantly, it accounts for misses of the monetary target in the context of a strategy where monetary growth is always important for monetary policy-making. Hence, we expect the interest rate rule implied by this loss function to provide a useful starting point for the empirical analysis undertaken in Section 5.

In order to derive the interest rate rule implied by the modified loss function (4.8), we need a model of the underlying structural relationships between the target variables. To keep the analysis as simple as possible, we assume that these relationships are adequately captured by the standard New Keynesian model which, despite its well-known limitations, is the workhorse in the theory of monetary policy-making.

Specifically, we use the baseline version of the model which consists of an aggregate supply and an aggregate demand equation, augmented by the simple money demand relation (4.2): ${ }^{29}$

$$
\begin{aligned}
& \pi_{t}-\pi_{t}^{*}=\beta\left(E_{t} \pi_{t+1}-\pi_{t+1}^{*}\right)+\kappa x_{t}+u_{t}^{\pi} \\
& x_{t}=E_{t} x_{t+1}-\varphi\left(i_{t}-E_{t} \pi_{t+1}-r_{t}^{n}\right) \\
& \left(m_{t}-p_{t}\right)=\eta_{y} \cdot y_{t}-\eta_{i} \cdot i_{t}+\varepsilon_{t}^{m d}
\end{aligned}
$$

where $u_{t}^{\pi}$ is a cost-push shock and $r_{t}^{\pi}$ is a natural-rate shock. For simplicity's sake, we assume that both are i.i.d. Combining Eq (4.2) with the definition of the money growth target from $\mathrm{Eq}(4.4 \mathrm{a})$ yields:

\footnotetext{
${ }^{29}$ For details on the model, see Woodford, 2007, p. 6f.
} 


$$
\begin{aligned}
\Delta m_{t}-\Delta m_{t}^{*}= & \pi_{t}-\pi_{t}^{*}+\eta_{y}\left(\Delta y_{t}-\Delta y_{t}^{*}\right)-\eta_{i} \Delta i_{t}+\left\{\Delta \varepsilon_{t}^{m d}-\Delta \varepsilon_{t}^{v^{*}}\right\} \\
& =\pi_{t}-\pi_{t}^{*}+\eta_{y} \Delta x_{t}-\eta_{i} \Delta i_{t}+\Delta \varepsilon_{t}
\end{aligned}
$$

where $\varepsilon_{t}=\varepsilon_{t}^{m d}-\varepsilon_{t}^{v^{*}}$ and we have again assumed that the money growth target is regularly updated to take account of observed portfolio shifts and of revisions in the central bank's estimates of potential output growth. Alternatively, the shock variable in (4.11) would have to be modified to include shocks to potential output growth. ${ }^{30}$

Clearly, the model misses some important elements for understanding monetary policy making, such as the role of financial factors in the transmission mechanism. Nevertheless, it does provide a simple and workable framework to discuss the key issues of commitment, credibility and reputation (see, for example, Gaspar and Kashyap, 2007).

We are now in a position to derive the interest rate rule implied by the modified period loss function (4.8) subject to the underlying model composed of Eq. (4.9), (4.10) and (4.11a). Formally, the solution can be found by minimising the Lagrangian expression:

$$
L_{t}=E_{t}\left[\begin{array}{l}
\left(\pi_{t}-\pi_{t}^{*}\right)^{2}+\hat{\lambda}_{x} x_{t}^{2}+\hat{\lambda}_{i}\left(i_{t}-i_{t}^{*}\right)^{2}+\hat{\lambda}_{m}\left(\Delta m_{t}-\Delta m_{t}^{*}\right)^{2} \\
+\beta\left(\pi_{t+1}-\pi_{t+1}^{*}\right)^{2}+\beta \hat{\lambda}_{x} x_{t+1}^{2}+\beta \hat{\lambda}_{i}\left(i_{t+1}-i_{t+1}^{*}\right)^{2}+\beta \hat{\lambda}_{m}\left(\Delta m_{t+1}-\Delta m_{t+1}^{*}\right)^{2}+\beta^{2} \ldots \\
+\phi_{1, t}\left(\beta\left(E_{t} \pi_{t+1}-\pi_{t+1}^{*}\right)+\kappa x_{t}+u_{t}^{\pi}-\left(\pi_{t}-\pi_{t}^{*}\right)\right) \\
+\phi_{3, t}\left(\pi_{t}-\pi_{t}^{*}+\eta_{y} \Delta x_{t}-\eta_{t} \Delta i_{t}+\Delta \varepsilon_{t}-\left(\Delta m_{t}-\Delta m_{t}^{*}\right)\right) \\
+\beta \phi_{1, t+1}\left(\beta\left(E_{t+1} \pi_{t+2}-\pi_{t+2}^{*}\right)+\kappa x_{t+1}+u_{t+1}^{\pi}-\left(\pi_{t+1}-\pi_{t+1}^{*}\right)\right) \\
+\beta \phi_{2, t+1}\left(E_{t+1} x_{t+2}-\varphi\left(i_{t+1}-E_{t+1} \pi_{t+2}-r_{t+1}^{n}\right)-x_{t+1}\right) \\
+\beta \phi_{3, t+1}\left(\pi_{t+1}-\pi_{t+1}^{*}+\eta_{y} \Delta x_{t+1}-\eta_{i} \Delta i_{t+1}+\Delta \varepsilon_{t+1}-\left(\Delta m_{t+1}-\Delta m_{t+1}^{*}\right)\right)+\ldots
\end{array}\right]
$$

with respect to the paths of each of the four endogenous variables, $\pi_{t}, x_{t}, \Delta m_{t}$ and $i_{t}$. The derivation is complicated by the fact that the money growth target introduces lagged values of the endogenous variables into the state vector. In any stationary equilibrium therefore, the expected values of the endogenous variables will depend on their own lagged values. ${ }^{31}$ In

\footnotetext{
${ }^{30}$ Loss function (4.8) assumes that output is targeted at the natural rate, which is a time-varying variable. If output-gap targeting is feasible, the value of the natural rate must be known (or, in real-life terms, a good estimate is available). Therefore, $\mathrm{y}_{\mathrm{t}}{ }^{\mathrm{n}}$ can, in principle, also serve as an input for the (time-varying) money growth target. See Jensen, 2002, p. 948.

${ }^{31}$ See Clarida et al.(1999), p. 1692, FN 74, or Walsh (2003).
} 
general, analytical solutions to this kind of problem are not available, but Söderlind (1999) and Dennis (2007) have developed algorithms which provide numerical solutions. While we do not want to take that route here, it is possible to gain important insights into the nature of the policy problem by considering the analytical solution to the much simpler static version of the problem. ${ }^{32}$ Hence, in what follows we assume that when taking interest rate decisions, the Bundesbank Council was concerned only with minimizing the current period loss function, taking private sector expectations as given. In this case, (4.12) reduces to:

$$
L_{t}=E_{t}\left[\begin{array}{l}
\left(\pi_{t}-\pi_{t}^{*}\right)^{2}+\hat{\lambda}_{x} x_{t}^{2}+\hat{\lambda}_{i}\left(i_{t}-i_{t}^{*}\right)^{2}+\hat{\lambda}_{m}\left(\Delta m_{t}-\Delta m_{t}^{*}\right)^{2} \\
+\phi_{1, t}\left(\beta\left(E_{t} \pi_{t+1}-\pi_{t+1}^{*}\right)+\kappa x_{t}+u_{t}^{\pi}-\left(\pi_{t}-\pi_{t}^{*}\right)\right) \\
+\phi_{2, t}\left(E_{t} x_{t+1}-\varphi\left(i_{t}-E_{t} \pi_{t+1}-r_{t}^{n}\right)-x_{t}\right) \\
+\phi_{3, t}\left(\pi_{t}-\pi_{t}^{*}+\eta_{y} \Delta x_{t}-\eta_{i} \Delta i_{t}+\Delta \varepsilon_{t}-\left(\Delta m_{t}-\Delta m_{t}^{*}\right)\right)
\end{array}\right]
$$

and the first-order conditions are:

$$
\frac{\partial L}{\partial\left(\pi_{t}-\pi_{t}^{*}\right)}=2\left(\pi_{t}-\pi_{t}^{*}\right)-\phi_{1, t}+\phi_{3, t}=0
$$

for all $\mathrm{t}$

$$
\frac{\partial L}{\partial x_{t}}=2 \hat{\lambda}_{x} x_{t}+\phi_{1, t} \kappa-\phi_{2, t}+\phi_{3, t} \eta_{y}=0
$$

$$
\frac{\partial L}{\partial i_{t}}=2 \hat{\lambda}_{i}\left(i_{t}-i_{t}^{*}\right)-\phi_{2, t} \varphi-\phi_{3, t} \eta_{i}=0
$$

$$
\frac{\partial L}{\partial\left(\Delta m_{t}-\Delta m_{t}^{*}\right)}=2 \hat{\lambda}_{m}\left(\Delta m_{t}-\Delta m_{t}^{*}\right)-\phi_{3, t}=0
$$

Solving for the Lagrangian multipliers and inserting the solutions into (4.13c) yields:

$$
\hat{\lambda}_{i}\left(i_{t}-i_{t}^{*}\right)-\varphi \hat{\lambda}_{x} x_{t}-\varphi \kappa\left(\pi_{t}-\pi_{t}^{*}\right)-\left(\varphi \kappa+\varphi \eta_{y}+\eta_{i}\right) \hat{\lambda}_{m}\left(\Delta m_{t}-\Delta m_{t}^{*}\right)=0
$$

which can be transformed into an (implicit) instrument rule of the form:

$$
i_{t}=i_{t}^{*}+\frac{\lambda_{x} \varphi}{\lambda_{i}} x_{t}+\frac{\kappa \varphi}{\lambda_{i}}\left(\pi_{t}-\pi_{t}^{*}\right)+\frac{\lambda_{m} \varphi}{\lambda_{i}}\left(\kappa+\frac{\eta_{i}}{\varphi}+\eta_{y}\right)\left(\Delta m_{t}-\Delta m_{t}^{*}\right)
$$

\footnotetext{
${ }^{32}$ For a similar approach, see Guender and Oh (2006).
} 
Eq (4.15) reproduces the well-known result that the implicit interest rule under discretion takes the form of a standard Taylor rule. However, the inclusion of a money growth term in the loss function implies an additional interest rate response to deviations of money growth from target. Interestingly, the Euler equations ("targeting rules") derived by Dennis (2007) for the case of fully optimal discretionary policy take essentially the same form as Eq (4.15). This suggests that the functional form of the policy rule (4.15) is not specific to the simple oneperiod optimization problem considered here, but carries over to the much more complex intertemporal optimization problem. ${ }^{33}$ Note, however, that in order to apply the Dennis algorithm to the problem described by Eq (4.12), the model has to be extended to include the first difference of the interest rate in the vector of endogenous variables. ${ }^{34}$ As a consequence, under fully optimal discretionary policy, the current interest rate will be a function of the first difference of the interest rate as well as of all the variables included in Eq (4.15).

In order to test whether the Bundesbank attached any weight to its money growth targets (relative to other potential targets), we could stop the analysis here and estimate Eq (4.15) directly. This is the route taken by most empirical studies, such as Clarida et al.(1998). However, in order to make the policy rule implied by the modified loss function (4.8) more directly comparable with other types of simple interest rate rules, we do not follow this approach here, but instead repeat the above exercise and eliminate the money growth term from Equation (4.15). The process of elimination of money growth deviations from the policy rule mimics the steps we have taken above for the case of pure money growth targeting. To simplify the procedure, we first re-write Eq (4.15) as:

$$
i_{t}=i_{t}^{*}+\frac{\Gamma_{2}}{\Gamma_{1}} x_{t}+\frac{\Gamma_{3}}{\Gamma_{1}}\left(\pi_{t}-\pi_{t}^{*}\right)+\frac{\Gamma_{4}}{\Gamma_{1}}\left(\Delta m_{t}-\Delta m_{t}^{*}\right)
$$

with $\Gamma_{1}=\hat{\lambda}_{i}, \Gamma_{2}=\hat{\lambda}_{x} \varphi, \Gamma_{3}=\varphi \kappa, \Gamma_{4}=\hat{\lambda}_{m}\left(\varphi \kappa+\eta_{i}+\varphi \eta_{y}\right)$

and then use Eq (4.11) to substitute out the money growth term:

$$
i_{t}=i_{t}^{*}+\frac{\Gamma_{2}}{\Gamma_{1}} x_{t}+\frac{\Gamma_{3}}{\Gamma_{1}}\left(\pi_{t}-\pi_{t}^{*}\right)+\frac{\Gamma_{4}}{\Gamma_{1}}\left(\pi_{t}-\pi_{t}^{*}+\eta_{y} \Delta x_{t}-\eta_{i} \Delta i_{t}+\Delta \varepsilon_{t}\right)
$$

\footnotetext{
${ }^{33}$ See Dennis (2007), Eq (25).

${ }^{34}$ The model is closed by including the definition of the additional variable, $\Delta i_{t}=i_{t}-i_{t-1}$, among the model equations. See Dennis (2007), Technical Appendix.
} 
Finally, solving for $i_{t}$, we get:

$$
\begin{aligned}
i_{t}= & \frac{\Gamma_{1}}{\left(\Gamma_{1}+\Gamma_{4} \eta_{i}\right)} i_{t}^{*}+\frac{\Gamma_{2}}{\left(\Gamma_{1}+\Gamma_{4} \eta_{i}\right)} x_{t}+\frac{\left(\Gamma_{3}+\Gamma_{4}\right)}{\left(\Gamma_{1}+\Gamma_{4} \eta_{i}\right)}\left(\pi_{t}-\pi_{t}^{*}\right)+\frac{\Gamma_{4} \eta_{y}}{\left(\Gamma_{1}+\Gamma_{4} \eta_{i}\right)} \Delta x_{t} \\
& +\frac{\Gamma_{4}}{\left(\Gamma_{1}+\Gamma_{4} \eta_{i}\right)} \Delta \varepsilon_{t}+\frac{\Gamma_{4} \eta_{i}}{\left(\Gamma_{1}+\Gamma_{4} \eta_{i}\right)} i_{t-1}
\end{aligned}
$$

According to (4.18), the interest rate rule of a central bank that targets money growth differs from a standard Taylor rule in that it implies a response to the deviation of actual output growth from potential output growth (which is equivalent to targeting the change in the output gap) as well as a response to the lagged interest rate and to the difference between the "true" money demand shock and the portfolio shock observed by the central bank. As shown by Giannoni and Woodford (2003), responding to the lagged interest rate (interest rate inertia) and to the change rather than the level of the output gap (history dependence) are both features of the optimal commitment policy. (4.18) therefore nicely illustrates the argument put forth by Söderström (2005) that money growth targeting may play a useful role in overcoming the stabilisation bias of discretionary policy. The response to money demand shocks implied by $\mathrm{Eq}(4.18)$ is usually viewed as a major drawback of monetary targeting. However, it cannot be established a priori how serious this problem is when the central bank takes into account portfolio shifts when implementing monetary targeting (as routinely practiced by the Bundesbank ). In section 5 we attempt to look at the relevant empirical evidence.

Equation (4.18) is the basis for the interest rate rule that we will estimate in the next section. ${ }^{35}$ As before, the intuition presented is predicated on some restrictions on the behavior of the error term in the money demand equation. We will further discuss the issue in section 5 below.

\footnotetext{
${ }^{35}$ In the simple model above we do not consider lags in monetary transmission. In the empirical results we will see that forecast inflation performs better than current inflation. Transmission lags can rationalize such result (see comments in section 5).
} 


\section{The Conduct of Monetary Policy and Monetary Policy Rules}

In this section, our goal is to provide a systematic comparison of policy rules followed in Germany, the US and the UK. To allow for a fair comparison, our aim was to use model specifications for each of the three countries that are as similar as possible regarding the dynamic structure and the corresponding variables. In order to provide a more precise characterization of systematic differences in the conduct of monetary policy, we estimate and compare interest rate reaction functions. The specification of the estimated reaction functions is based on the interest rate rule derived in the previous section, which includes the elements of a standard Taylor rule as well as the features implied by including a money growth target in the loss function.

\subsection{Brief reference to the literature}

There is a voluminous literature about monetary policy reaction functions, especially as regards the US. According to the established view, there was a regime shift around October 1979 (the start of the Volcker disinflation) ${ }^{36}$. The broad strand of the empirical literature sees the main difference between the pre-Volcker period and the Volcker-Greenspan period as pertaining to the interest response to an increase in inflation (or expected inflation). Specifically, the claim is that the coefficient, measuring the interest rate response to inflation was significantly below unity during the pre-Volcker period and significantly above unity in the later period. An inflation coefficient below unity corresponds to accommodative monetary policy as real interest rates decline in response to an inflation increase (see, for example, Clarida et al., 1998, 2000 or Lubik and Schorfheide, 2004). In other words, before 1979 US monetary policy does not comply with the Taylor principle. Characterization of monetary policy in the interim period, between 1979 and 1982, is difficult as it seems dominated by transition dynamics induced by the Fed's monetary experiment. Moreover, the Fed's policy response to economic slack also seems difficult to pin down. Orphanides $(2003,2004)$ goes as far as to argue that the key distinction does not involve the response to expected inflation, but rather the response to policymakers' real-time perceptions of real activity (excess demand). Using real-time data to re-estimate the Fed's policy rule, he finds that, prior to Volcker's appointment, policy was too responsive to perceived output gaps. Specifically, loose

\footnotetext{
${ }^{36}$ See Beyer and Farmer (2007) for an econometric investigation and Gaspar et al. (2006) for an analytical narrative drawing on the documentary evidence provided in Lindsey et al.(2005).
} 
monetary policy was a consequence of responding strongly to overestimations of economic slack. More recent papers (Boivin, 2006, Kim and Nelson, 2006, Partouche, 2007), using a time-varying coefficients framework, find important, but gradual changes in the Fed's response to both inflation and real activity, not properly accounted for by the typical splitsample approach.

\subsection{A comparison of empirically estimated policy rules}

As a starting point for a comparative analysis of German and US monetary policy reaction functions during the Great Inflation, it is useful to take another look at the relative inflation performance of the two countries from the mid-1960s to the early 1980s. According to Figure 5.1, the upsurge of inflation in Germany in the early 1970s was stopped by quick disinflation which preceded the Volcker disinflation by about six years. Still, the dating of the regime shift is not as straightforward for Germany as it is for the US, where the appointment of Paul Volcker as Chairman provides an obvious date for a structural break. Two potential candidates are the break down of the Bretton Woods System in March 1973 and/or the official start of the monetary targeting regime in $1975 \mathrm{Q} 1 .^{37}$ However, most studies on the Bundesbank's reaction function, including Clarida et al. (1998) and Gerberding, Seitz and Worms $(2005,2007)$, choose an even later date, namely 1979Q1, as the starting point of their analysis. The reason for doing so can best be understood by comparing the behaviour of real interest rates and inflation during the period in question.

As shown in Figure 5.2, pre-1979 the US real rate steadily declines as inflation rises, becoming persistently negative during most of the seventies. In late 1979, the real rate rose sharply, leading to a subsequent decline in inflation. This observation provides the rationale for the analysis in Beyer and Farmer (2007). They argue that the source of the inflation buildup in the 1970s was a downward drift in the real interest rate that was translated into a simultaneous increase in unemployment and inflation by passive Fed policy. For Germany, the picture is different. Real interest rates rose sharply after the break-down of the Bretton Woods System in March 1973. Moreover, real interest rates were (almost) always significantly positive throughout the period. Nevertheless, the early increase in real interest rates was almost completely reversed in 1974/75 and the real rate was kept rather low until

\footnotetext{
${ }^{37}$ The Bundesbank had already established an internal monetary target for its own orientation for the year 1974 (see Dudler, 1980, p. 299), so 1974Q1 may be considered another potential breakpoint.
} 
the beginning of 1979 (data: inflation measured by CPI inflation against previous quarter, real rates calculated by subtracting period $\mathrm{t}+1$ inflation from three-month money market rates, three-quarter centered moving averages). Overall, however, the visual comparison between the conduct of monetary policy in Germany and the US in the 1970s suggests loose monetary policy in the latter country, but not in Germany.

In the remainder of this section, our aim is to characterize differences in monetary policy in terms of differences in the estimated monetary policy reaction functions. In order to be better able to capture empirical regularities, we extend the interest rate rule derived in the previous section - Eq (4.18) - in two directions. First, the theoretical model of Section 4 was silent on the frequency of the data, but it is usually taken to describe regularities observed in quarterly data and in quarterly rates of change. However, when applying the model to the Bundesbank's monetary policy, we have to take account of the fact that the Bundesbank's money growth targets were annual targets which referred to money growth over the previous four quarters. Hence, in the empirical application of Eq (4.18), we extend the time horizon of the inflation and output growth variables to annual (four-quarter) rates of change. Secondly, we allow for forward-looking behaviour on part of the policymakers, that is, we allow them to focus on expected rather than current inflation. This modification of Eq (4.18) can be rationalised by lags in the transmission of monetary policy impulses which are not accounted for in the baseline New Keynesian model. ${ }^{38}$ Thirdly, in order to capture interest rate dynamics not accounted for by the first lag of the interest rate, we also included the second lag of the interest rate among the endogenous variables. Hence, we start from a specification of the following form:

$$
i_{t}=\left(1-\rho_{1}-\rho_{2}\right)\left(\begin{array}{l}
\alpha+\beta E\left(\left(\pi_{t+n}^{a}-\pi^{*}\right) \mid \Omega_{t}\right)+\gamma_{1} E\left(\left(y_{t}-y_{t}^{*}\right) \mid \Omega_{t}\right) \\
+\gamma_{2} E\left(\Delta_{4}\left(y_{t}-y_{t}^{*}\right) \mid \Omega_{t}\right)+\frac{\gamma_{2}}{\eta_{y}}\left(\Delta_{4} \varepsilon_{t}^{m d}-\Delta_{4} \varepsilon_{t}^{v^{*}}\right)
\end{array}\right)+\rho_{1} i_{t-1}+\rho_{2} i_{t-2}+u_{t}
$$

where $E\left(\pi_{t+n}^{a} \mid \Omega_{t}\right)$ is policymakers' inflation forecast for period $t+n$ formed in $t$ on the basis of the information available at time $\mathrm{t}, \pi^{a}$ denotes annual inflation, $E\left(\left(y_{t}-y_{t}^{*}\right) \mid \Omega_{t}\right)$ is policymakers' estimate of the current output gap, again formed on the basis of information available at the time, $u_{t}$ is an error term and $\Delta_{4}$ denotes changes over the previous four

\footnotetext{
${ }^{38}$ Strictly speaking, this argument is valid only for the part of the interest rate response to inflation which derives directly from the inflation stabilization objective in the loss function (4.8). Therefore, we also estimated
} 
quarters. An important issue is the method used to generate the forecasts of inflation, the output gap and the output growth gap. Unfortunately, as regards the Bundesbank, real-time forecasts of these variables over the relevant time horizons and at the appropriate frequency do not exist. Therefore, we follow the method first proposed by McCallum (1976) and proxy the unobserved forecasts by the corresponding realizations (see Clarida et al., 1998). Hence, the error term $u_{t}$ is a linear combination of the forecast errors and the exogenous disturbance term. In order to keep the forecast errors as small as possible, we use the initial (unrevised) figures on inflation and output as well as the first available estimates of the output gap. ${ }^{39}$ To avoid endogeneity problems, these variables are instrumented by a vector of variables $I_{t}$ which were part of policymakers' real-time information sets and which are orthogonal to the error term $u_{t}$ (for details on the instrument sets, see Table 5.1-5.3).

Finally, for empirical tractability, the model requires a sufficiently stable empirical money demand function. Reviewing the empirical literature on money demand we are confident that this condition is fulfilled as there is broad evidence for the existence of sufficiently stable cointegrated money demand models. In conventional cointegrated money demand models money is usually explained by output (e.g. GDP, serving as a scale variable), and one or more suitable interest rate variables that represent own rates and opportunity costs for holding money. Derivations of actual money from the long-run money demand relationship $\left(m-m^{*}\right)$ are then interpreted as stationary (i.e. transitory) money demand shocks, corresponding to the level of $\varepsilon_{t}$ in (4.18). For example, Beyer (1998) finds a stable cointegrated long run money demand function for German M3 over the sample period 1975 1994 with stationary money demand shocks. The standard deviation of their first differences is $4.6 \%$, compared with a standard deviation of $3.5 \%$ for the year-on-year growth rate of money. Similarly, Baba et al.(1992) find a stable long-run money demand function for US M1 for the sample period 1960 - 1988 and likewise see Hendry and Ericsson (1991a) for UK M1 over the sample 1963-1989. ${ }^{40}$ Hence we believe that the empirical model (5.1) is a valid approximation for empirically estimating our modified theoretical Taylor rule (4.18).

specifications of the interest rate reaction function which allow for a response to current as well as expected future inflation. However, not surprisingly, in these exercises one of the two terms usually drops out.

${ }^{39}$ See Gerberding et al. (2005), p. $279 \mathrm{f}$. .

${ }^{40}$ Using annual data Hendry and Ericsson (1991b) find a stable long-run money demand function for US M1 over the sample period 1878-1970. 
We first report our findings for Germany which are summarized in Table 5.1. The estimates are based on the real-time data set described in Gerberding et al. (2004). In order to compare the conduct of monetary policy in Germany before and after the collapse of Bretton Woods, the data set was extended backwards to 1965 so that it now covers the sample period 19651998. ${ }^{41}$ As formal tests for structural break do not yield unambiguous results, we present estimates for three different break points, with the Bretton Woods/Pre-Monetary Targeting samples ending in 1973Q1, 1974Q4 and 1978Q4, respectively. In Table 5.1, we only report results for a forward-looking specification of the reaction function where the horizon of the inflation forecast variable has been set to four quarters. However, in order to check the robustness of the results to changes in the horizon of the inflation variable, we conducted the exercise for different horizons of the inflation forecast, reaching from $n=0$ to $n=4$, and found that the results were qualitatively the same. ${ }^{42}$ Our estimations also established that the term $\left(\Delta_{4} \varepsilon_{t}^{m d}-\Delta_{4} \varepsilon_{t}^{v^{*}}\right)$ does not play a major econometric role. In theory, this term is unobservable. Point estimates and standard errors of regressors in model (5.1) remain virtually unaffected whether an empirical proxy of that term is included or not. However, as part of a money demand shock this error variable has interesting policy implications which we will discuss further below (see 5.3).

The analysis yields a number of interesting results. First, we find that the coefficient $\beta$, which captures the interest rate response to inflation, is significantly below one before the introduction of monetary targeting (that is, for the sample periods 65Q1-73Q1 and 65Q174Q4, respectively), but significantly above one afterwards (that is, for the samples starting in 75Q1 and later). Note, however, that the standard error of the inflation coefficient and of the equation is lowest for the (arguably more stable) 1979-1998 period. From this, we conclude that the Bundesbank respected the Taylor principle (responded to a rise in (expected) inflation in a stabilizing way) right from the beginning of the monetary targeting regime. This contrasts with empirical estimates of standard Taylor rules for the US over the 1970s. Second, the response to the perceived output gap, $\gamma_{1}$, is significantly positive with point estimates about 0.5 in the Bretton Woods/pre-Monetary Targeting sub-samples. By contrast, it is close to zero

\footnotetext{
${ }^{41}$ The first vintage of Bundesbank estimates of potential output that we were able to reconstruct dates from April 1972 (Bundesbank, AR 1971). In order to go back beyond this date, we proxied the unavailable "true" realtime data by the estimates dating from April 1972. We think this justifiable since there are no indications of major revisions during the time span 1965-1972. For instance, the estimates of the German output gap in the 1960s published by the OECD in April 1970 (see OECD, 1970) are very similar to the estimates that we reconstructed from the April 1972 vintages of Bundesbank data on actual and potential output.

${ }^{42}$ Results available from authors on request.
} 
and insignificant under monetary targeting. If one follows Orphanides (2003), the lack of response to real-time estimates of the output gap, which at the time were heavily biased downwards in most countries, may also have been an important reason for Germany's superior inflation performance after the regime shift. Thirdly, the coefficient on the output growth gap, which is insignificant before the introduction of monetary targeting, becomes highly significant afterwards. According to our theoretical model, this is an important feature which distinguishes the Bundesbank's policy under monetary targeting from a purely discretionary approach. Hence, we interpret this result as evidence that the money growth targets did bring the Bundesbank policy closer to the (otherwise not feasible) optimal commitment solution. Fourthly, we find a significant degree of interest rate inertia, captured by $\rho$, in all sub-sample periods, with point estimates about 0.6 before and about 0.8 after the regime change. The high degree of inertia after the regime shift is in accordance with the predictions of the theoretical model as well as with the Bundesbank's often professed preference for conducting policy with a steady hand ("Politik der ruhigen Hand"). ${ }^{43}$

Tables 5.2a and $\mathrm{b}$ present the results for a very similar formulation for the US. We use the three months T-Bill rate as a short term interest rate. Regarding the explanatory variables, inflation is again measured by year-on-year changes in CPI. For the output gap, $\left(y_{t}-y_{t}^{*}\right)$, we use the real-time perceptions of the US output gap reconstructed by Orphanides (2003). We report results for annual changes in the output gap as well as for its quarterly changes. Notice, that for the US we normalize the inflation target $\pi^{*}$ at zero. For the forward-looking element, we use inflation expectations one period ahead that are formed at period t. In Table 5.2a, we use real-time inflation forecasts based on Greenbook data (as in Orphanides 2003, 2004), whereas in Table 5.2b, we use the lead of revised inflation data. For interest rate smoothing we restricted ourselves to reporting the case of one lag only ${ }^{44}$.

For analyzing the US we follow the strategy that is common in the empirical literature and estimate over samples that correspond to the chairmanships of Burns - Miller and Volcker Greenspan. Using quarterly data we consider the period 1970Q1 - 1979Q2 ("the Burns-Miller

\footnotetext{
${ }^{43}$ In Gerberding et al. (2007), we show that for the sample period 1979Q1 to 1998Q4, this result is robust to the inclusion of an AR(1)-model for the error term.

${ }^{44}$ We also estimated the models with two lags and got very similar quantitative and the same qualitative results compared to the one lag only specification.
} 
period") and the period 1983Q1 - 1998Q4 (“the Volcker-Greenspan period"). The omitted interim period is characterized by transitional dynamics and does not yield useful estimates.

We are able to reproduce a number of well known findings. First, for real time inflation forecast data (see Tab. 5.2a) we can replicate Orphanides' (2003) findings with a Taylor coefficient greater than unity also in the Burns-Miller period whereas for revised inflation data (Tab. 5.2b) the Taylor coefficient on inflation is significantly below unity in the BurnsMiller period and significantly above one in the Volcker-Greenspan period. Second, the coefficient on the lagged interest rate is much larger in the latter period (becoming close to one). Third, and focusing on formulation with the annual measure of the change in the output gap, the coefficient on the output gap is always significant, at the $5 \%$ level, except for the Volcker - Greenspan period in case of quarterly changes of the output gap (see Tab. 5.2b, 3rd row). Regarding the history dependence of monetary policy we find significant differences between the US and Germany. For the US the coefficients for both, quarterly or annual changes in the output gap is insignificant during the 1970s. Conversely, it is highly significant during the 1980s and 1990s whereas for Germany it is significant throughout the entire postBretton Woods sample period. The comparison of the models for Germany and the US between Table 5.1 and Table 5.2a,b therefore suggests that the conduct of monetary policy in the US and Germany differed during the 1970s but after 1983, US monetary policy approached the practice that the Bundesbank followed since 1975.

Turning to the case of UK, already from eyeballing Figures 2.1-3 one would expect, with respect to Germany but to a lesser extent also to the US, very different empirical results for any estimated Taylor rule. Compared to US and Germany inflation in UK peaked highest, interest rates during the 1970s were at a much higher level whereas growth performance was comparatively much weaker than in US or Germany. In order to explain the UK three-month T-bill rate, we use the real-time perceptions of the UK output gap reconstructed by Nelson and Nikolov (2003). For future inflation we use revised data, analogue to Table 5.2b for the US The results in Table 5.3 confirm our priors. Interest rates in the 1970s appear to follow a near-unit root process. Neither output nor inflation gap are remotely significant. This changes only later in the 1980s and 1990s, when the output gap remains insignificant but the Taylor coefficient on inflation is estimated rather tightly at 1.5 . 


\subsection{The role of money demand shocks}

As pointed out in the previous subsection, dealing with the term $\left(\Delta_{4} \varepsilon_{t}^{m d}-\Delta_{4} \varepsilon_{t}^{v^{*}}\right)$ has interesting policy implications. The term represents those (exogenous) changes in money demand that are not identified and accounted for by the central bank. Ignoring this term in the empirical model implies an assumption that the central bank - in our case the Bundesbank did not make systematic mistakes in identifying shocks to money demand. Under this assumption, the variable $\left(\Delta_{4} \varepsilon_{t}^{m d}-\Delta_{4} \varepsilon_{t}^{v^{*}}\right)$ will be a white noise (or at least stationary) process which can be subsumed as, say, $\tilde{u}_{t}$, into the error term of Eq (5.1). However, we are aware that our framework also has testable implications for the Bundesbank's response to unidentified disturbances to money demand. ${ }^{45}$ Specifically, we would expect to find that policy was tightened in response to an increase in this variable and vice versa. Unfortunately, since we do not have reliable information on the magnitude of the portfolio shocks observed by the Bundesbank, in real time, $\varepsilon_{t}^{v^{*}}$, we cannot test this hypothesis directly. However, as a robustness check, we conducted an alternative test which is based on the assumption that the Bundesbank was able to identify a fraction $\delta$ of the "true" money demand shock so that $\varepsilon_{t}^{\nu^{*}}=\delta \varepsilon_{t}^{m d}$ holds. Under this assumption, we can rewrite Eq (5.1) as:

$$
i_{t}=\left(1-\rho_{1}-\rho_{2}\right)\left(\begin{array}{l}
\alpha+\beta E\left(\left(\pi_{t+n}^{a}-\pi^{*}\right) \mid \Omega_{t}\right)+\gamma_{1} E\left(\left(y_{t}-y_{t}^{*}\right) \mid \Omega_{t}\right) \\
+\gamma_{2} E\left(\Delta_{4}\left(y_{t}-y_{t}^{*}\right) \mid \Omega_{t}\right)+\frac{\gamma_{2}}{\eta_{y}}(1-\delta) \Delta_{4} \varepsilon_{t}^{m d}
\end{array}\right)+\rho_{1} i_{t-1}+\rho_{2} i_{t-2}+u_{t}
$$

where $\delta$ denotes the fraction of the "true" money demand shock that the Bundesbank was able to identify. In the special case when $\delta=1$ the Bundesbank could identify all shocks as portfolio shocks, whereas if $\delta=0$ the shock to money demand remained unreduced. Using the residuals from the money demand model of Beyer (1998) to estimate Eq (5.1a), we find that the coefficient $\delta$ is highly significant, with a point estimate of $0.77 .{ }^{46}$ On the other hand, the fact that our estimate of $\delta$ is also significantly different from one suggests that the Bundesbank did react to shocks to money demand which it was unable to identify in real time. Specifically, when money growth increased as a consequence of a non-identified disturbance to money demand, the Bundesbank would tighten policy, in contrast with what would be the case under perfect information. This empirical finding is in line with the testable implication

\footnotetext{
${ }^{45}$ We thank our discussant Benjamin Friedman bringing this important point to our attention. .

${ }^{46}$ Results available from Andreas Beyer on request.
} 
from the theoretical model presented in the previous section. Nevertheless, the relatively high value of $\delta$ suggests that the Bundesbank was able to identify most money demand disturbances in real time. Hence, it responded to such shocks in a much muted way, thereby limiting the volatility of policy rates.

\subsection{Summary}

To sum up, the empirical results for Germany, US, and UK suggest that monetary policy in the three countries was conducted very differently in the 1970s. For Germany and US estimating a Taylor rule for that period produces reasonable results but reveals different policy strategies. Money as a commitment device has worked well for Germany and is reflected by a significant coefficient in changes of the output gap variable. For the US we do not find any similar history dependence in the data for the 1970s but we do find it for the Volcker-Greenspan period in the 1980s and 1990s. By sharp contrast, monetary policy in the UK has been very different both with respect to US and Germany. Our empirical findings do not allow for any Taylor-type characterization of UK monetary policy in the 1970s and only very vaguely for the 1980 s and 1990s. 


\section{Conclusion}

In this paper we examine an important episode in European monetary history. We investigate the conduct of monetary policy in Germany in the 1970s and the 1980s. It was during this period that the Bundesbank acquired its credibility and reputation as a bulwark against inflation. Our goal was to illustrate how the monetary growth targeting strategy, followed by the Bundesbank since 1975, contributed to this success. We wanted, as much as possible, to examine the strategy as conceived, communicated and refined by the Bundesbank itself. Naturally we are not able to do full justice to the Bundesbank's approach. We can only present a simplified (stylized) view of the conduct of monetary policy in that period.

Nevertheless, we think that by focusing on anchoring inflation and inflation expectations, we capture a fundamental aspect of the interaction between monetary policy and the behavior of economic agents. Using a standard new Keynesian model and a modified loss function (incorporating money growth deviations) we are able to explain the role of money growth targeting as a commitment device. Under some mild conditions regarding the existence of a stable money demand function which are fulfilled at least for Germany for the time period under consideration, we are able to derive a role for money as a commitment device, succeeds even in the context of the new Keynesian model (in which money plays no active role).

The operation of monetary growth targeting as a commitment device is compatible with target misses, even repeatedly. In the modified loss function framework monetary growth targeting is permanently relevant and imposes structure on the monetary policy reaction function. Nevertheless, given that monetary deviations from target have to be traded off against other arguments in the loss function frequent deviations from target cannot be excluded. In practice, the Bundesbank had to account for the determinants of observed deviations and explain how, in the end, it would deliver on the final goal of price level stability.

A standard objection to monetary targeting is that it induces unwarranted volatility in policy rates in response to unidentified disturbances to money demand. In the context of our theoretical model, it is the case that the central bank will tighten in response to non-observed positive shocks to money demand. Empirically, we find this holds true for the Bundesbank. Nevertheless, empirical evidence shows that money demand was stable in Germany during the period. Moreover, the Bundesbank appears to have been able to take into account most 
special factors in real time. Hence, the response of policy to money demand disturbances was much attenuated, limiting the relevance of this concern for the historical performance of the Bundesbank.

Issing in his Stone Lecture (Issing et al., 2005) affirms: "The Bundesbank missed its target roughly half of the time ... This does not mean, however, that the Bundesbank did not take monetary targets seriously. On the contrary, money growth targets were regarded as constituting the basis for a rules-oriented approach to monetary policy. Announcing a monetary target implied a commitment by the Bundesbank towards the public. Deviations of money growth from the target had always to be justified. Even if it is true that the reputation of the Bundesbank ultimately was achieved by its success in fulfilling its mandate to safeguard the stability of its currency, its final goal, current policy continuously had to be justified in the context of its pre-announced strategy. In this sense, the strategy contributed to the transparency, the accountability and the credibility of Bundesbank's policy."

From our theoretical framework we derive an interest rate rule. Using real-time data, we find that it closely approximates the monetary policy, as it was conducted by the Bundesbank, in the period of 1975 to 1998 . The main finding is that the Bundesbank response to the output growth gap was highly significant. Such response is a characteristic of the conduct of monetary policy under commitment. It is also robust policy against problems in the measurement of the level of potential output in real time. A similar response to the growth gap was not present in the reaction function of the Federal Reserve System during the BurnsMiller period. It does become significant, for the US, in the later Volcker-Greenspan period. We were able to characterize systematic monetary policy for Germany and the US. Our empirical findings suggest a much less stable approach in the UK. 


\section{REFERENCES}

Alesina, A. and Summers, L. (1990), Central bank independence and macroeconomic performance, discussion paper, Harvard University.

Baba, Y., D. F. Hendry, and R. M. Starr (1992), The Demand for M1 in the U.S.A., 19601988, Review of Economic Studies, 59, 1, 25-61.

Bade, R. and Parkin, M (1980), Central bank laws and monetary policy, discussion paper, University of Ontario.

Baltensperger, E. (1999), Monetary policy under conditions of increasing integration (197996), in: Deutsche Bundesbank (ed.), Fifty years of the deutsche Mark - Central Bank and the currency in Germany since 1948, Oxford University Press, pp. 419-523.

Barro, R. J. and D. B. Gordon (1983a), A Positive Theory of Monetary Policy in a Natural Rate Model, Journal of Political Economy 91, 589-610.

Barro, R. J. and D. B. Gordon (1983b), Rules, Discretion and Reputation in a Model of Monetary Policy, Journal of Monetary Economics 12, 101-121.

Barsky, R. B. and L. Kilian (2002), Do We Really Know that Oil Caused the Great Stagflation? A Monetary Alternative, NBER Macroeconomic Annual 2001, Cambridge: MIT Press pp. 137-183.

Barsky, R. B. and L. Kilian (2004), Oil and the Macroeconomy since the 1970s, Journal of Economic Perspectives, vol. 18(4), pages 115-134, Fall.

Bayoumi, T, H Faruqee, B. Hunt, D. Laxton, J. Lee, A. Rebucci, I. Tchakarov and P.D. Karam (2004), GEM: A New International Macroeconomic Model, IMF Occasional Papers 239, International Monetary Fund.

Beyer, A. (1998), Modelling Money Demand in Germany, Journal of Applied Econometrics, Vol. 13 (1), 57-76. 
Beyer, A. and R. Farmer (2007), Natural Rate Doubts, Journal of Economic Dynamics and Control, 31 (2007) 797-825

Blinder, A. (1979), Economic Policy and the Great Stagflation, New York: Academic Press.

Bordo, M. (1993), The Bretton Woods International Monetary System: A Historical Overview, in M. Bordo and B. Eichengreen (eds.), A Retrospective on the Bretton Woods System, Chicago: University of Chicago Press.

Boivin, J. (2006), Evidence from Drifting Coefficients and Real-Time Data, Journal of Money, Credit and Banking, 38(5), August 2006.

Brunner, K. (1983), Has monetarism failed?, Cato Journal Vol. 3, No. 1, pp. 23-62.

Bruno, M and J. Sachs (1985), Economics of Worldwide Stagflation, Cambridge: Harvard University Press

Buchheim, C. (1999), The Establishment of the Bank deutscher Länder and the West German Currency Reform, in: Deutsche Bundesbank (ed.), Fifty Years of the deutsche Mark - Central Bank and the currency in Germany since 1948, Oxford University Press, pp. 55-100.

Christiano, L., R. Motto and M. Rostagno (2008), Two Reasons Why Money and Credit May be Useful in Monetary Policy, in A. Beyer and L. Reichlin (eds.), The role of money: money and monetary policy in the 21 st century, ECB, Frankfurt.

Clarida, R. and M. Gertler (1997), How the Bundesbank Conducts Monetary Policy, in C. Romer and D. Romer (eds.), Reducing Inflation: Motivation and Strategy, Chicago, 363-412.

Clarida, R., J. Galí, and M. Gertler (1998), Monetary Policy Rules in Practice: Some International Evidence, European Economic Review 42, 1033-1067.

Clarida, R., Galí, J., Gertler, M. (1999), The science of monetary policy, Journal of Economic Literature 37, 1661-1707. 
Clarida, R., J. Galí and M. Gertler (2000), Monetary Policy Rules and Macroeconomic Stability: Evidence and Some Theory, Quarterly Journal of Economics 115, 147-180.

Coenen, C., K. Christoffel and A. Warne (2008), The new area wide model of the Euro area: a micro founded open economy model for forcasting and policy analyses, ECB Working Paper Series, $\mathrm{N}^{\circ} 944$, October.

Darby, M.R. (1982), The Price of Oil and World Inflation and Recession, American Economic Review, 72(4), September, p.

Dennis, R. (2007), Optimal Policy In Rational Expectations Models: New Solution Algorithms, Macroeconomic Dynamics. 11(01), 31-55.

Dudler, H.-J. (1980), Examination of Witnesses: Hermann-Josef Dudler, Testimony, November 10, 1980, in Treasury and Civil Service Committee, Monetary Policy Volume II: Minutes of Evidence, 297-307. London: HMSO, 1981.

Deutsche Bundesbank, Annual Report, Various years.

Edge, R.M, M.T. Kiley and J-P. Laforte (2007), Documentation of the Research and Statistics Divisions Estimated DSGE Model of the U.S. Economy: 2006 Version, FED Reserve Board Discussion Paper 2007-53.

Erceg, C L. Guerrieri, and C. Gust (2006), SIGMA: A New Open Economy Model for Policy Analysis, International Journal of Central Banking, vol. 2(1), March., 1-50.

Fratianni, M. and J. von Hagen (2001), The Konstanz Seminar on monetary theory and policy, European Journal of Political Economy, Vol. 17, 641-664.

Frenkel, J. and M. Goldstein (1999), The International Role of the Deutsche Mark, in Deutsche Bundesbank (ed.) Fifty Years of the Deutsche Mark: Central Bank and Currency in Germany since 1948, Oxford: Oxford University Press. 
Galí, J. (2008), Monetary Policy, Inflation and the Business Cycle: An Introduction to the New Keynesian Framework, Princeton: Princeton University Press.

Garber, P. (1993), The Collapse of the Bretton Woods Fixed Exchange Rate System, in M. Bordo and B. Eichengreen (eds.), A Retrospective on the Bretton Woods System, Chicago: University of Chicago Press.

Gaspar, V. and A. Kashyap (2007), Stability First: Reflections Inspired by the ECB's Success as the ECB's Chief Economist, in Monetary Policy: A Journey from Theory to Practice, Frankfurt, ECB

Gaspar, V., F. Smets and D. Vestin (2006), Monetary Policy over Time, Macroeconomic Dynamics, 10 (02), 207-229.

Gaspar, V., F. Smets, and D. Vestin (2007), Is Time Ripe for Price Level Path Stability? ECB Working Paper Series, No. 818.

Gerberding, C., F. Seitz and A. Worms (2004), How the Bundesbank really conducted monetary policy: An analysis based on real-time data, Deutsche Bundesbank Discussion Paper Series1, No 25/2004.

Gerberding, C., F. Seitz and A. Worms (2005), How the Bundesbank Really Conducted Monetary Policy, North American Journal of Economics and Finance 16, 277-292.

Gerberding, C., F. Seitz and A. Worms (2007), Money-Based Interest Rules, Lessons from German Data, Deutsche Bundesbank Discussion Paper Series 1, No. 06/2007.

Giannoni, M. P. and M. Woodford (2003), How Forward-Looking is Optimal Monetary Policy?, Journal of Money, Credit and Banking 35 (6, Part 2), 1425-69.

Gordon, R. (1975), Alternative Responses to External Supply Shocks, Brookings Papers on Economic Activity, 1: 183-206. 
Guender, A. V. and D. Y. Oh (2006), Price stability through price-level targeting or inflation targeting? A tale of two experiments, Journal of Economics and Business, 58(5-6), 373-391.

von Hagen, J. (1995), Inflation and Monetary Targeting in Germany, in Leonard Leidermann and Lars Svensson (eds.), Inflation Targets, CEPR.

von Hagen, J. (1999), A New Approach to Monetary Policy (1971-78), in Deutsche Bundesbank (ed.) Fifty Years of the Deutsche Mark: Central Bank and Currency in Germany since 1948, Oxford: Oxford University Press.

Hamilton, J. (1983), Oil and the Macroeconomy since World War II, Journal of Political Economy, 91 (2), 228-248.

Hendry, D. F. and N. R. Ericsson (1991a), Modelling the demand for narrow money in the United Kingdom and the United States, European Economic Review, 35(4), 33-86.

Hendry, D. F. and N. R. Ericsson (1991b), An econometric analysis of UK money demand in monetary trends in the United States and the United Kingdom by Milton Friedman and Anna J. Schwartz, American Economic Review, 81(1), 8-38.

Issing, O. (1992): Theoretical and Empirical Foundations of the Deutsche Bundesbank's Monetary Targeting, Intereconomics 27, 289-300.

Issing, O. (1993), Central Bank Independence and Monetary Stability, The Institute of Economic affairs, Occasional Paper 89, London.

Issing, O. (1997), Monetary Targeting in Germany: The Stability of Monetary Policy and of the Monetary System, Journal of Monetary Economics, June 1997, 39(1), pp. 67-79.

Issing, O. (2005), Why did the Great Inflation not happen in Germany?, Federal Reserve Bank of St. Louis Review, March/April, 329-336. 
Issing, O. (2006), Europe's hard fix: the Euro area, International Economics and Economic Policy, Vol. 3, No 3-4, pp. 181-196.

Issing, O., V.Gaspar, O. Tristani and D. Vestin (2005), Imperfect knowledge and monetary policy, The Stone Lectures in Economics, Cambridge University Press.

Jensen, H., (2002), Targeting nominal income growth or inflation?, American Economic Review 92, 928-956.

Kilponen, J. and K. Leitemo (2008), Model Uncertainty and Delegation: A Case for Friedman's k-percent Money Growth Rule?, Journal of Money, Credit, and Banking, forthcoming.

Kim, C. and C. Nelson (2006), Estimation of a Forward-Looking Monetary Policy Rule: A Time-Varying Parameter Model using Ex-Post Data," Journal of Monetary Economics 53 (Nov.), 1949-66.

Kydland, F. and E. Prescott (1977), Rules Rather than Discretion: The Inconsistency of Optimal Plans, Journal of Political Economy 85, 473-491.

Lindsey, D., A. Orphanides and R. Rasche (2005), The Reform of October 1979: How it Happened and Why, Finance and Economics Discussion Paper, Federal Reserve Board.

Lubik, T. A. and F. Schorfheide (2004), Testing for indeterminacy: An application to U.S. monetary policy, American Economic Review, 94(1), 190-217.

McCallum, B. (1976): Rational Expectations and the Estimation of Econometric Models: an Alternative Procedure, International Economic Review, 17, 484-90.

Nelson, E. and K. Nikolov (2003), UK Inflation in the 1970s and 1980s: The Role of Output Gap Mismeasurement, Journal of Economics and Business, July/August 2003, 55(4), pp. 35370. 
Nelson, E. (2007), The Great Inflation and Early Disinflation in Japan and Germany International Journal of Central Banking, December 2007, 3(4), 23-76.

Nessén, M. and D. Vestin (2005), Average Inflation Targeting, Journal of Money, Credit and Banking 37, 837-863.

Neumann, M. J. M. (1997), Monetary Targeting in Germany, in: I. Kuroda (ed.), Towards more effective monetary policy, Hampshire, pp. 176-198.

Neumann, M. J. M. (1999), Monetary Stability: Threat and Proven Response, in Deutsche Bundesbank (ed.) Fifty Years of the Deutsche Mark: Central Bank and Currency in Germany since 1948, Oxford: Oxford University Press.

Neumann, M. J. M. (2006), Pre-commitment and Guidance - Lessons from the Bundesbank's History, in: European Central Bank (ed.), Monetary Policy - A Journey from Theory to Practice, Frankfurt 2006, 5-13 (forthcoming).

OECD (1970), Economic Survey of Germany, April 1970.

Orphanides, A. (2003), Historical Monetary Policy Analysis and the Taylor Rule, Journal of Monetary Economics 50, 983-1022.

Orphanides, A. (2004), Monetary Policy Rules, Macroeconomic Stability and Inflation: A View from the Trenches, Journal of Money, Credit and Banking, 36, 151-157.

Partouche, H. (2007), Time-Varying Coefficients in a GMM Framework: Estimation of a Forward Looking Taylor Rule for the Federal Reserve, Banque de France Working Paper No. 177, September 2007.

Richter, R. (1999), German monetary policy as reflected in the academic debate, in: Deutsche Bundesbank (ed.), Fifty years of the deutsche Mark - Central Bank and the currency in Germany since 1948, Oxford University Press, pp. 525-571. 
Rogoff, K. (1985), The optimal degree of commitment to an intermediate monetary target, Quarterly Journal of Economics, 100 (4), 1169-89.

Røisland, Øistein (2006), Inflation Inertia and the Optimal Hybrid Inflation / Price Level Target, in Journal of Money Credit and Banking

Sachverständigenrat zur Begutachtung der gesamtwirtschaftlichen Entwicklung (1974), Vollbeschäftigung für Morgen, Stuttgart.

Samuelson, P. (1974), Worldwide Stagflation, in Nagatani and Crowley (eds.), Collected Scientific Papers vol. 4, Cambridge MIT Press, 1977.

Schlesinger, H. (1980), Notenbankpolitik: weiter am kurzen Zügel, Wirtschafts Woche, 1980, Jg. 34, Heft 5, pp. 77-80.

Schlesinger, H. (1983), The Setting of Monetary Objectives in Germany, in P. Meek (ed.), Central Bank Views of Monetary Targeting. New York: Federal Reserve Bank of New York, 1983, pp. 6-17.

Schlesinger, H. (1988), Das Konzept der Deutschen Bundesbank, in W. Ehrlicher und D. B. Simmert (eds.), Wandlungen des geldpolitischen Instrumentariums der Deutschen Bundesbank, Kredit und Kapital Supplement 10, Berlin, pp. 3-20.

Schlesinger, H. (2002), Die Bundesbank und ihre Geldpolitik, in B. Scheffold (ed.), Exogenität und Endogenität - Die Geldmenge in der Geschichte des ökonomischen Denkens und in der modernen Politik, Marburg, pp. 137-159.

Smets, F. and R. Wouters (2003), An estimated stochastic dynamic general equilibrium model of the euro area, Journal of European Economic Association, Vol 1 (5), 1123-1175.

Smets, F. and R. Wouters (2007), Shocks and frictions in US business cycles: a Bayesian DSGE approach, American Economic Review, 97(3), 586-607. 
Söderlind, P. (1999), Solution and estimation of RE macromodels with optimal policy, European Economic Review Papers and Proceedings, 43, 813-23.

Söderström, U. (2005), Targeting Inflation with a Role for Money, Economica 72, 577-596.

Svensson, L.E.O., (1999), Price level targeting vs. inflation targeting: a free lunch?, Journal of Money, Credit and Banking 31, 277-295.

Taylor, J. (1993), Discretion versus Policy Rules in Practice, Carnegie-Rochester Conference Series on Public Policy 39:195-214

Taylor, J. (1999), A Historical Analysis of Monetary Policy Rules, in John. B. Taylor (ed.), Monetary Policy Rules, Chicago: University of Chicago Press

Triffin, R. (1960), Gold and the Dollar Crisis, New Haven: Yale University Press.

Vestin, David (2006), Price-level versus inflation targeting, Journal of Monetary Economics $53,1361-1376$.

Walsh, Carl E. (2003), Speed Limit Policies: The Output Gap and Optimal Monetary Policy, American Economic Review, 93(1): 265-278.

Woodford, M. (1999), Optimal monetary policy inertia. Working Paper no. 7261, National Bureau of Economic Research.

Woodford, M. (2003), Interest and Prices: Foundations of a Theory of Monetary Policy, Princeton University Press.

Woodford, M. (2007), How Important is Money in the Conduct of Monetary Policy?, paper prepared for the Conference in Honor of Ernst Baltensperger, Bern, June 8, 2007.

Zweig, S. (1970), Die Welt von Gestern- Erinnerungen eines Europäers, Frankfurt, p. 359. 
Table 2.1: Selected Macroeconomic Indicators for G7 \& Switzerland

\begin{tabular}{|c|c|c|c|c|c|c|c|c|c|c|c|c|c|c|c|c|}
\hline & \multicolumn{2}{|c|}{$\begin{array}{c}\text { CA } \\
60-98\end{array}$} & \multicolumn{2}{|c|}{$\begin{array}{c}\mathrm{CH} \\
60-98\end{array}$} & \multicolumn{2}{|c|}{$\begin{array}{c}\mathrm{DE} \\
60-98\end{array}$} & \multicolumn{2}{|c|}{$\begin{array}{c}\text { FR } \\
60-98\end{array}$} & \multicolumn{2}{|c|}{$\begin{array}{c}\text { IT } \\
60-98\end{array}$} & \multicolumn{2}{|c|}{$\begin{array}{c}J P \\
60-98\end{array}$} & \multicolumn{2}{|c|}{$\begin{array}{c}\text { UK } \\
60-98\end{array}$} & \multicolumn{2}{|c|}{$\begin{array}{c}\text { US } \\
60-98\end{array}$} \\
\hline & me & s.d. & me & s.d & mea & s.d. & mea & s.d & mea & s.d & mea & s.d & mea & s.d & mea & s.d. \\
\hline CPI & 4.5 & 3.1 & 3.3 & 2. & 3.1 & 1.8 & 5.3 & 3.6 & 7.4 & 5. & 4.4 & 4.0 & 6.5 & 4. & 4.4 & 2.9 \\
\hline $\begin{array}{l}\text { \%p.a. } \\
\text { real GDP } \\
\text { \%p.a. }\end{array}$ & 3.6 & 2.1 & 2.3 & 2. & 2.7 & 2.0 & 3.3 & 1.9 & 3.4 & 2. & 4.5 & 4.0 & 2.4 & 1. & 3.4 & 2.0 \\
\hline $\begin{array}{l}\text { real Cons } \\
\% \text { p.a. }\end{array}$ & 3.2 & 2.4 & 2.6 & 2. & 3.3 & 2.8 & 3.0 & 2.1 & 3.7 & 2. & 4.4 & 3.7 & 2.1 & 2. & 2.9 & 2.3 \\
\hline $\begin{array}{l}\text { Empl } \\
\text { \%p.a. }\end{array}$ & 2.2 & 1.6 & 0.7 & 1. & 0.2 & 1.2 & 0.6 & 0.8 & 0.1 & 1. & 1.0 & 0.8 & 0.3 & 1. & 1.8 & 1.3 \\
\hline $\begin{array}{c}\text { Unemp } \\
\% p . a\end{array}$ & 7.7 & 2.4 & & & 5.4 & 3.6 & 6.5 & 3.9 & 8.2 & 2. & 2.2 & 0.9 & 6.3 & 3. & 6.0 & 1.5 \\
\hline $\mathrm{RL}$ & 8.5 & 2.6 & 4.6 & 1. & 7.1 & 1.5 & 8.3 & 2.9 & 10.4 & 4. & 6.0 & 2.3 & 9.4 & 2. & 7.4 & 2.5 \\
\hline RS & 7.2 & 3.5 & & & 5.3 & 2.3 & 7.7 & 3.4 & 11.7 & 4. & 6.0 & 3.0 & 8.3 & 3. & 6.0 & 2.7 \\
\hline
\end{tabular}


FIGURE 2.1. Inflation in G7 countries and Switzerland

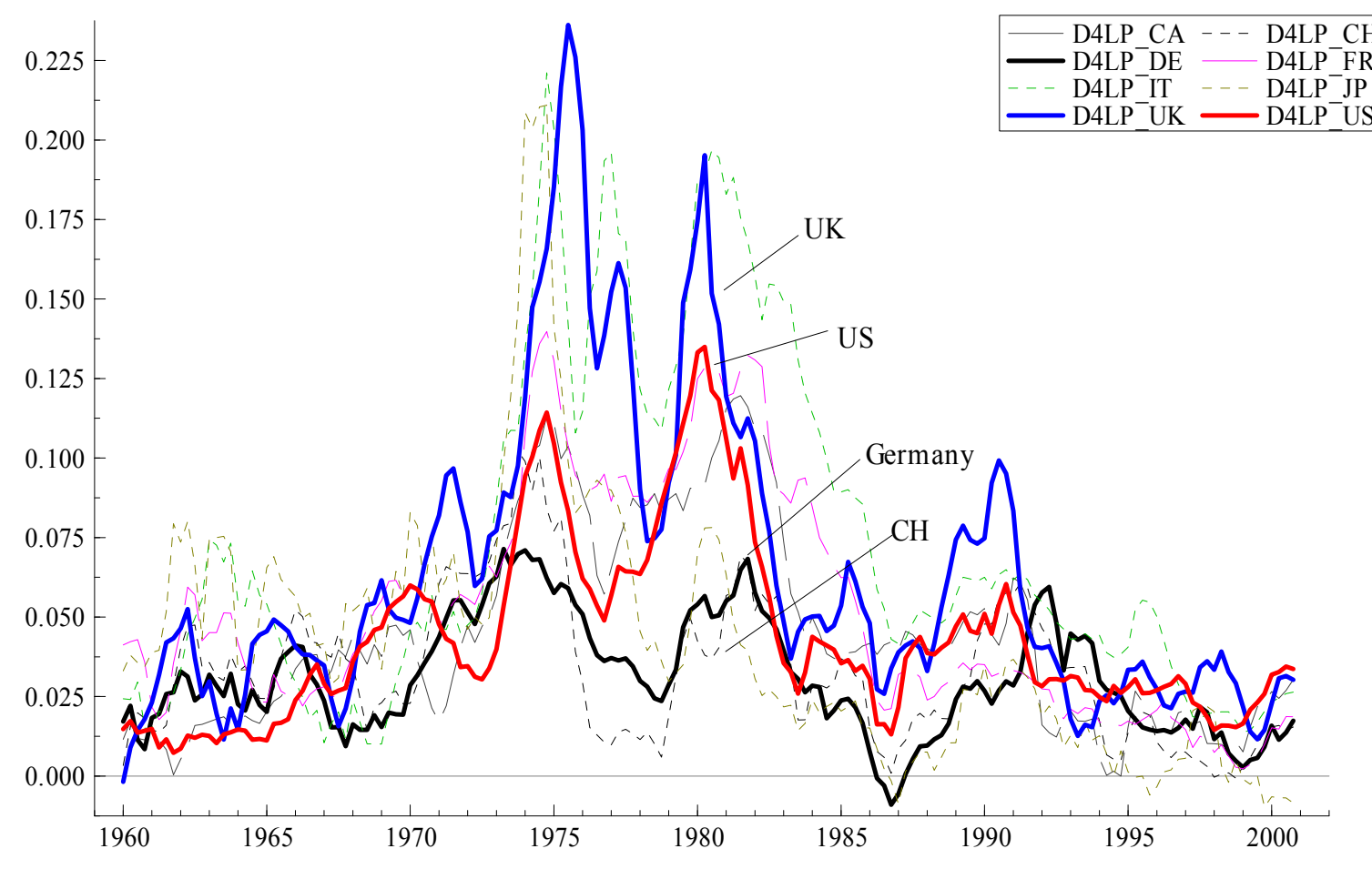


Figure 2.2: Average nominal interest rates in the 1970s

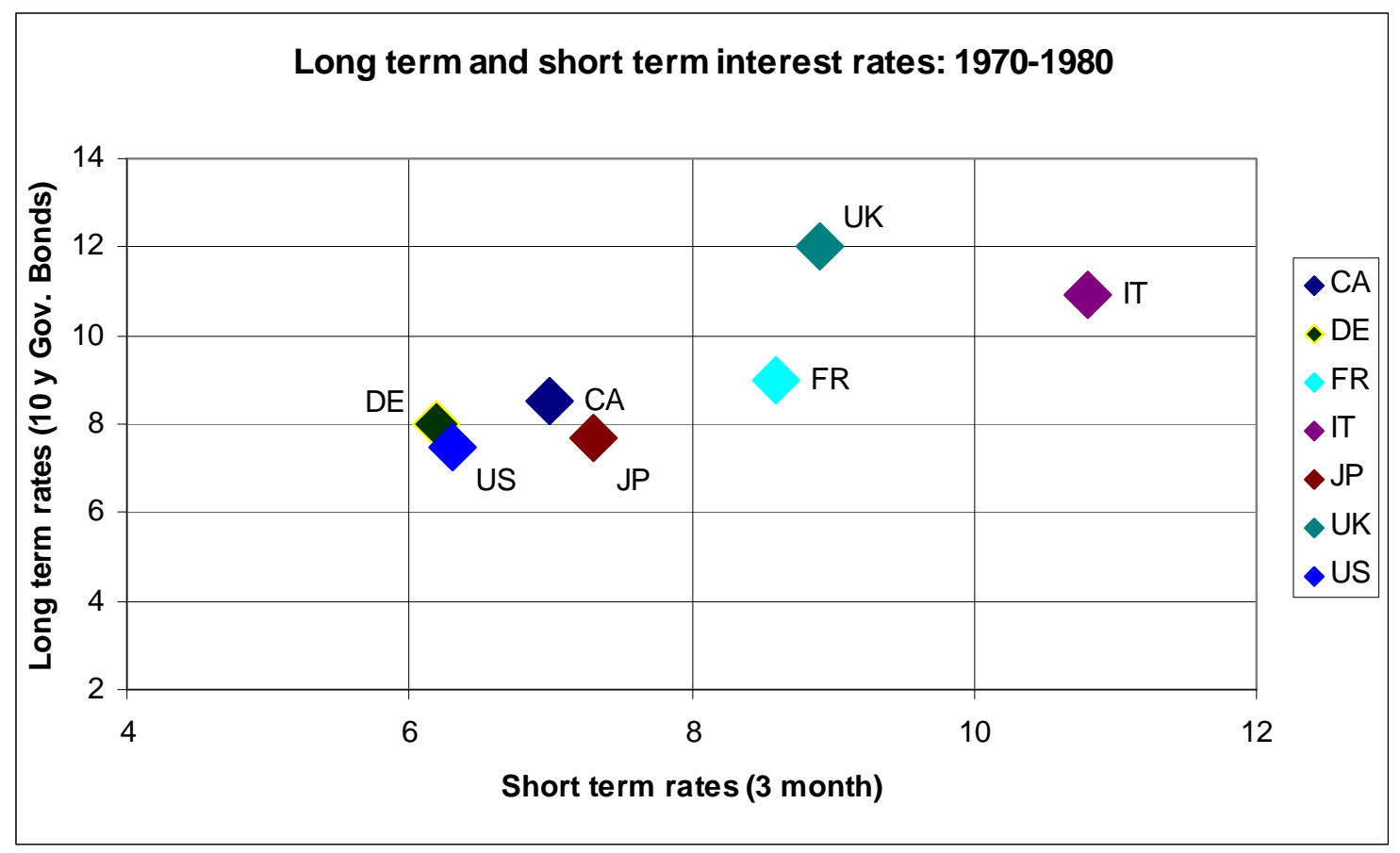

Figure 2.3: Average inflation and real growth rates in the 1970s

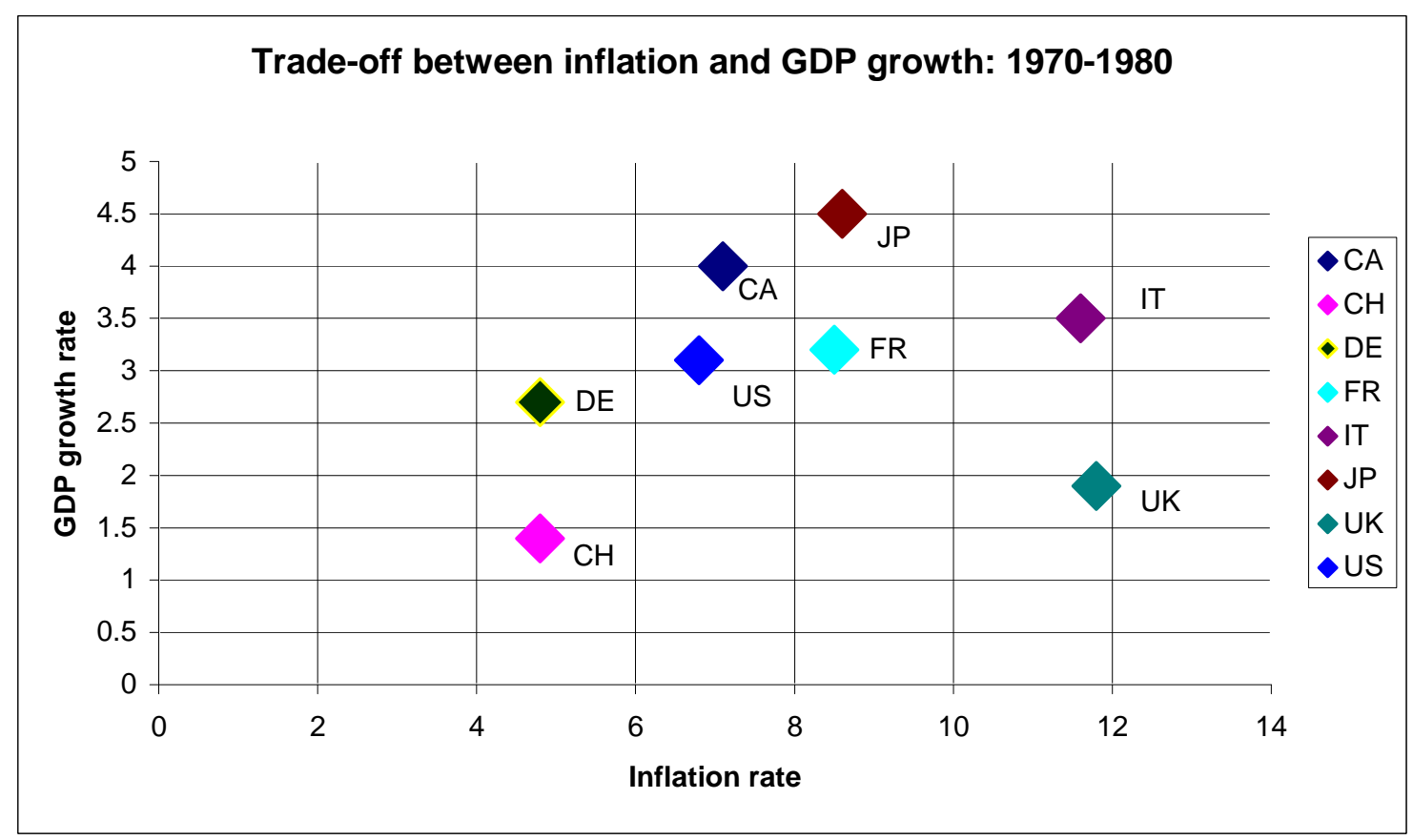


Table 3.1: Numerical inputs for the derivation of the money growth targets

Average annual changes in \%

\begin{tabular}{|c|c|c|c|c|c|c|c|}
\hline \multirow[t]{2}{*}{ Period } & \multirow{2}{*}{$\begin{array}{l}\text { Medium- } \\
\text { term price } \\
\text { assumption* }\end{array}$} & \multirow{2}{*}{$\begin{array}{l}\text { Expected } \\
\text { growth of } \\
\text { potential } \\
\text { output }\end{array}$} & \multicolumn{2}{|c|}{ Expected change in } & \multirow{2}{*}{$\begin{array}{l}\text { Envisaged } \\
\text { increase in } \\
\text { money } \\
\text { stock }\end{array}$} & \multirow[b]{2}{*}{ Target** } & \multirow[b]{2}{*}{ Sources } \\
\hline & & & $\begin{array}{l}\text { Capacity } \\
\text { utilisation }\end{array}$ & $\begin{array}{l}\text { Trend } \\
\text { velocity (-) }\end{array}$ & & & \\
\hline 1975 & \multicolumn{5}{|c|}{ no explicit derivation by single factors } & +8 & MR Dec. 74 \\
\hline 1976 & $+4 /+5$ & +2 & $+21 / 2$ & -1 & +8 & & $\begin{array}{l}\text { AR 76, MR } \\
\text { Jan. } 76\end{array}$ \\
\hline 1977 & 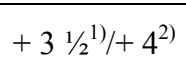 & +3 & +2 & -1 & +8 & $(6-7)$ & $\begin{array}{l}\text { AR 76, MR } \\
\text { Jan. } 77\end{array}$ \\
\hline 1978 & $+3 /+31 / 2$ & +3 & + & & +8 & $(5-7)$ & $\begin{array}{l}\text { AR 77, MR } \\
\text { Jan. } 78\end{array}$ \\
\hline 1979 & + & +3 & + & + & & $6-9$ & MR Jan. 79 \\
\hline 1980 & +4 & +3 & & -1 & $(+6)$ & $5-8$ & $\begin{array}{l}\text { AR } 79, \text { MR } \\
\text { Dec. } 79\end{array}$ \\
\hline 1981 & $+3 \frac{1}{2} /+4$ & $+21 / 2$ & & -1 & $+5 /+51 / 2$ & $4-7$ & $\begin{array}{l}\text { AR } 80, \text { MR } \\
\text { Dec. } 80\end{array}$ \\
\hline 1982 & $+31 / 2^{1)}$ & $+1 \frac{1 / 2 /+2}{2}$ & & 0 & $(+43 / 4)$ & $4-7$ & $\begin{array}{l}\text { AR 81, MR } \\
\text { Dec. } 81\end{array}$ \\
\hline 1983 & $+3 \frac{1}{2}$ & $+1 \frac{1 / 2}{2} /+2$ & & & & $4-7$ & MR Dec. 82 \\
\hline 1984 & +3 & +2 & & & +5 & $4-6$ & $\begin{array}{l}\text { AR 83, MR } \\
\text { Dec. } 83\end{array}$ \\
\hline 1985 & +2 & Over 2 & + & & $+4 \frac{1}{2}$ & $3-5$ & MR Dec. 84 \\
\hline 1986 & $+2^{1)}$ & $+21 / 2$ & & & $+41 / 2$ & $31 / 2-51 / 2$ & MR Jan. 86 \\
\hline 1987 & +2 & $+21 / 2$ & & & & $3-6$ & MR Jan. 87 \\
\hline 1988 & +2 & +2 & & $+1 / 2$ & & $3-6$ & MR Feb. 88 \\
\hline 1989 & +2 & $+2 /+21 / 2$ & & $+1 / 2$ & 5 & about 5 & MR Dec. 88 \\
\hline 1990 & +2 & $+21 / 2$ & & $+1 / 2$ & about 5 & $4-6$ & MR Dec. 89 \\
\hline $1991^{3)}$ & +2 & $\begin{array}{c}+2 \frac{1}{2}(+2 \\
1 / 4)^{3)}\end{array}$ & & $+1 / 2$ & & $4-6(3-5)^{3)}$ & $\begin{array}{l}\text { AR 90, MR } \\
\text { July } 91\end{array}$ \\
\hline 1992 & +2 & $+23 / 4$ & & $+1 / 2$ & & $31 / 2-51 / 2$ & MR Dec. 91 \\
\hline 1993 & +2 & +3 & & +1 & +6 & $41 / 2-61 / 2$ & MR Dec. 92 \\
\hline 1994 & +2 & $+21 / 2$ & & +1 & $+51 / 2$ & $4-6$ & MR Jan. 94 \\
\hline 1995 & +2 & $+23 / 4$ & & +1 & $+53 / 4$ & $4-6$ & MR Jan. 95 \\
\hline 1996 & +2 & $+21 / 2$ & & +1 & $+51 / 2$ & 4-7 & MR Jan. 96 \\
\hline 1997 & $+11 / 2 /+2$ & $+21 / 4$ & & +1 & +5 & $31 / 2-61 / 2$ & MR Jan. 97 \\
\hline 1998 & $+1 \frac{1}{2} /+2$ & +2 & & +1 & +5 & $3-6$ & MR Jan. 98 \\
\hline $\begin{array}{l}\text { *Before } \\
\text { currency } \\
\text { with bas } \\
\text { deflator; } \\
\text { review. }\end{array}$ & $\begin{array}{l}\text { 35: unavoidab } \\
\text { circulation pl } \\
\text { inuary 1974) } \\
\text { Explicit refer }\end{array}$ & $\begin{array}{l}\text { increase in } p \\
\text { required mir } \\
\text { til } 1987 \text { and } \\
\text { ce to consum }\end{array}$ & $\begin{array}{l}\text { e broad mo } \\
\text { r price inde }\end{array}$ & $\begin{array}{l}\text { s referred to } \\
\text { on domestic } \\
\text { y stock M3 } \\
\text { 3) Downwa }\end{array}$ & $\begin{array}{l}\text { ntral bank } \\
\text { eposits calc } \\
\text { reafter. 1) } \\
\text { correction }\end{array}$ & $\begin{array}{l}\text { ney stock }(d \mathrm{~d} \\
\text { ated at consta } \\
\text { plicit referen } \\
\text { arget range i }\end{array}$ & $\begin{array}{l}\text { fined as } \\
\text { at reserve ratio } \\
\text { e to GDP } \\
\text { midyear }\end{array}$ \\
\hline
\end{tabular}


Table 3.2: Monetary targets and their implementation

in $\%$

\begin{tabular}{|c|c|c|c|c|c|c|c|}
\hline \multirow[b]{2}{*}{ Year } & \multicolumn{3}{|c|}{$\begin{array}{l}\text { Target: } \\
\text { Growth of central bank money stock (1975- } \\
\text { 1987) or money stock M3 (from 1988) }\end{array}$} & \multicolumn{2}{|c|}{ Actual money growth } & \multirow[b]{2}{*}{$\begin{array}{l}\text { Target } \\
\text { achieved }\end{array}$} & \multirow[b]{2}{*}{$\begin{array}{l}\text { Inflation rate } \\
(\mathrm{CPI})^{4}\end{array}$} \\
\hline & $\begin{array}{l}\text { in the course } \\
\text { of the year }\end{array}$ & $\begin{array}{l}\text { annual } \\
\text { average }\end{array}$ & $\begin{array}{l}\text { midyear } \\
\text { review }\end{array}$ & $\begin{array}{l}\text { in the } \\
\text { course of } \\
\text { the year }\end{array}$ & $\begin{array}{l}\text { annual } \\
\text { average }\end{array}$ & & \\
\hline 1975 & 8 & & & $10.1(9.5)$ & 7.8 & no & 5.9 \\
\hline 1976 & & 8 & & $(9.0)$ & 9.2 & no & 4.2 \\
\hline 1977 & $(6-7)^{2}$ & 8 & & $(9.5)$ & 9.0 & no & 3.8 \\
\hline 1978 & $(5-7)^{2}$ & 8 & & $(12.1)$ & 11.4 & no & 2.7 \\
\hline 1979 & $6-9$ & & lower limit & 6.3 & 9.1 & yes & 4.1 \\
\hline 1980 & $5-8$ & (6) & lower half & 4.9 & 4.8 & yes & 5.4 \\
\hline 1981 & $4-7$ & $\left(5-5 \frac{1}{2}\right)$ & lower half & 3.5 & 4.4 & yes & 6.3 \\
\hline 1982 & $4-7$ & $(43 / 4)$ & Upper half & 6.0 & 4.9 & yes & 5.3 \\
\hline 1983 & $4-7$ & & Upper half & 7.0 & 7.3 & yes & 3.4 \\
\hline 1984 & $4-6$ & (5) & & 4.6 & 4.8 & yes & 2.3 \\
\hline 1985 & $3-5$ & $(41 / 2)$ & & 4.5 & 4.6 & yes & 2.2 \\
\hline 1986 & $3 \frac{1}{2}-51 / 2$ & $\left(4 \frac{1}{2}\right)$ & & 7.7 & 6.4 & no & -0.2 \\
\hline 1987 & $3-6$ & & & 8.1 & 8.1 & no & 0.3 \\
\hline 1988 & $3-6$ & & & 6.7 & 6.3 & no & 1.2 \\
\hline 1989 & about 5 & (just under 5) & & 4.7 & 5.7 & yes & 2.8 \\
\hline 1990 & $4-6$ & (about 5) & & 5.6 & 4.3 & yes & 2.7 \\
\hline 1991 & $4-6$ & $(5 / 51 / 4)$ & $3-5$ & 5.2 & 4.6 & yes & 3.6 \\
\hline 1992 & $31 / 2-51 / 2$ & $(5-51 / 4)$ & & 9.4 & 8.1 & no & 4.0 \\
\hline 1993 & $4 \frac{1}{2}-6 \frac{1}{2}$ & (6) & & 7.4 & 7.8 & no & 3.6 \\
\hline 1994 & $4-6$ & $(51 / 2)$ & & 5.7 & 9.0 & yes & 2.7 \\
\hline 1995 & $4-6$ & $(53 / 4)$ & & 2.1 & 0.6 & no & 1.8 \\
\hline 1996 & $4-7$ & $(51 / 2)$ & & 8.1 & 7.5 & no & 1.4 \\
\hline $1997^{3}$ & $31 / 2-61 / 2$ & & & 4.7 & 6.2 & yes & 1.9 \\
\hline $1998^{3}$ & $3-6$ & & & 5.5 & 4.4 & yes & 1.0 \\
\hline Mean & & & & 6.6 & 6.5 & & 3.0 \\
\hline $\begin{array}{l}1 \text { Bety } \\
\text { Dec. } 1 \\
1997 / 1\end{array}$ & he fourth qua & er of the previo & s year and th & fourth quar & $\begin{array}{l}\text { of the cl } \\
\text { abedded }\end{array}$ & $\begin{array}{l}\text { t year; } 19 \\
\text { wo-year o }\end{array}$ & $\begin{array}{l}\text { ec. } 1974 \text { to } \\
\text { tation for }\end{array}$ \\
\hline
\end{tabular}




\section{Figure 3.1: Money Growth Targets 1975-1998}

1975-1987: Targetsfor the central bankmoney stock Change against previous year in $\%$

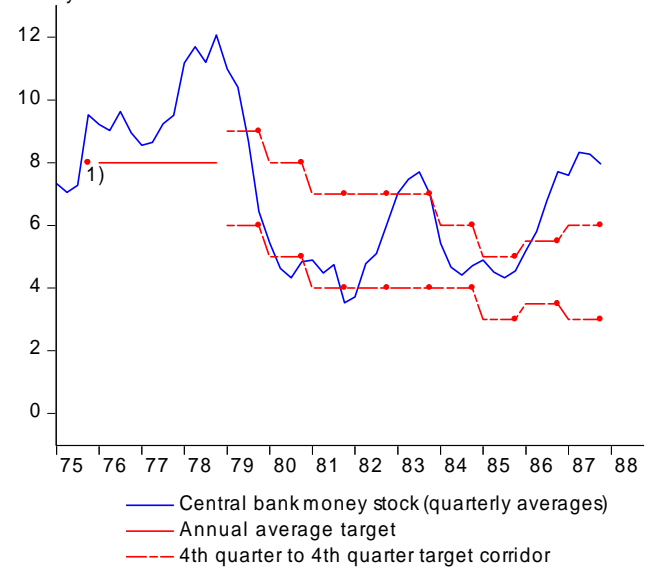

1) Point target for Dec. 1974 to Dec. 1975
1988-1998: Targets for the money stock M3

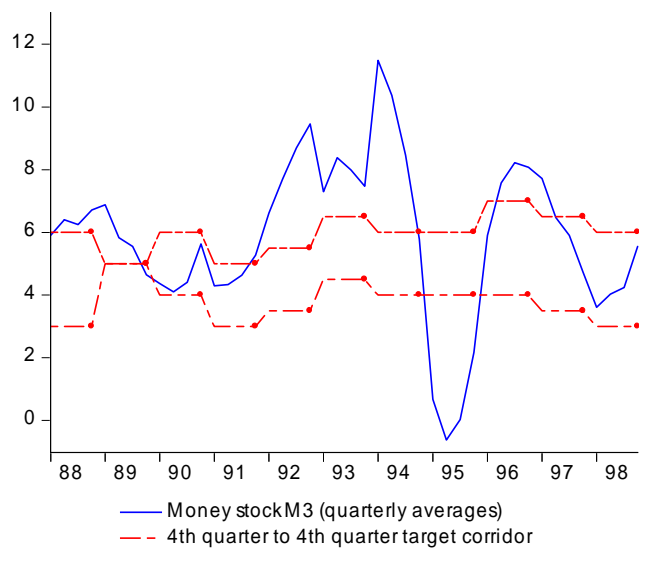


Figure 5.1: Inflation in Germany and the US (consumer prices, quarterly data)

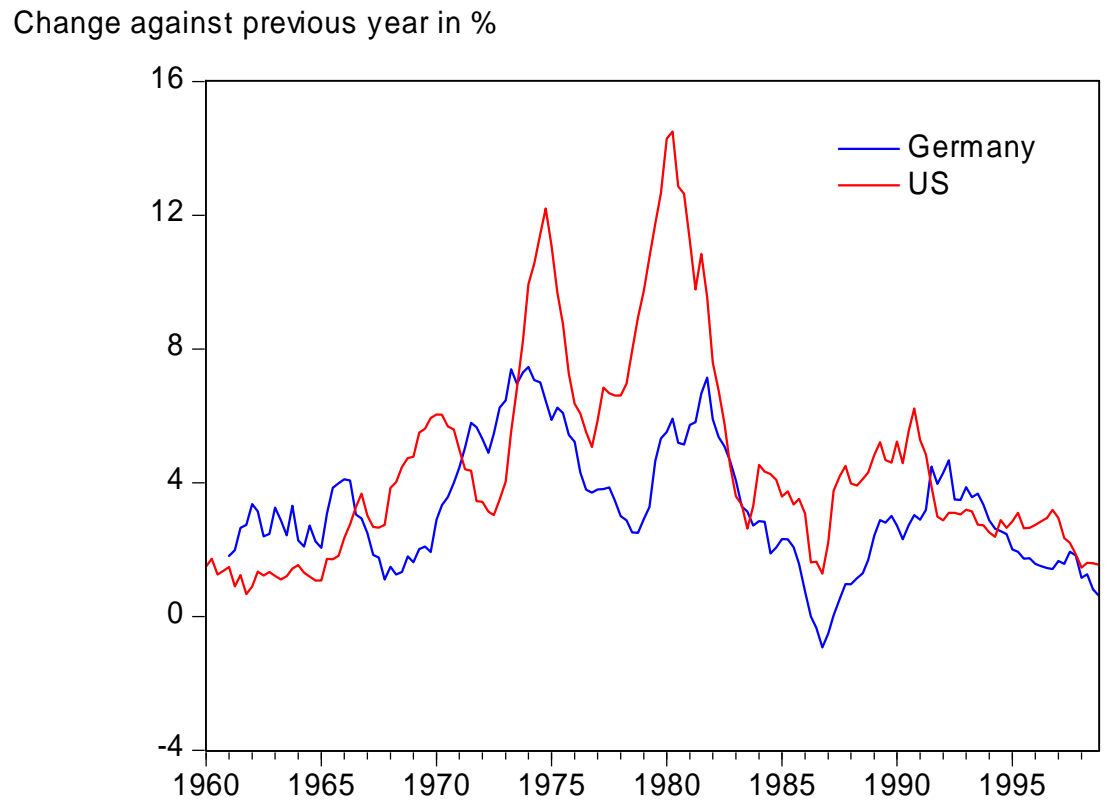


Figure 5.2a: Interest Rates and Inflation in Germany

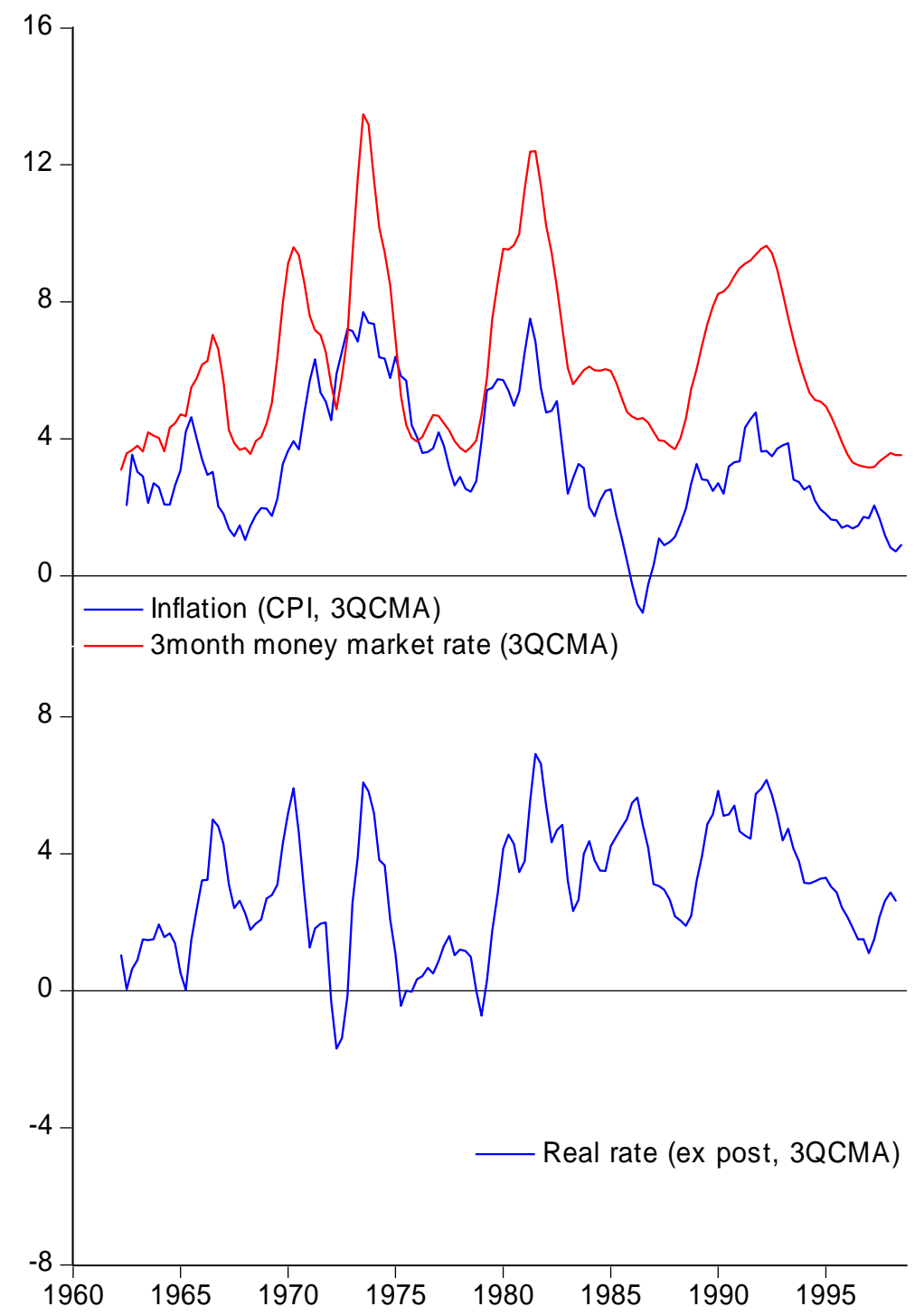


Figure 5.2b: Interest Rates and Inflation in the US

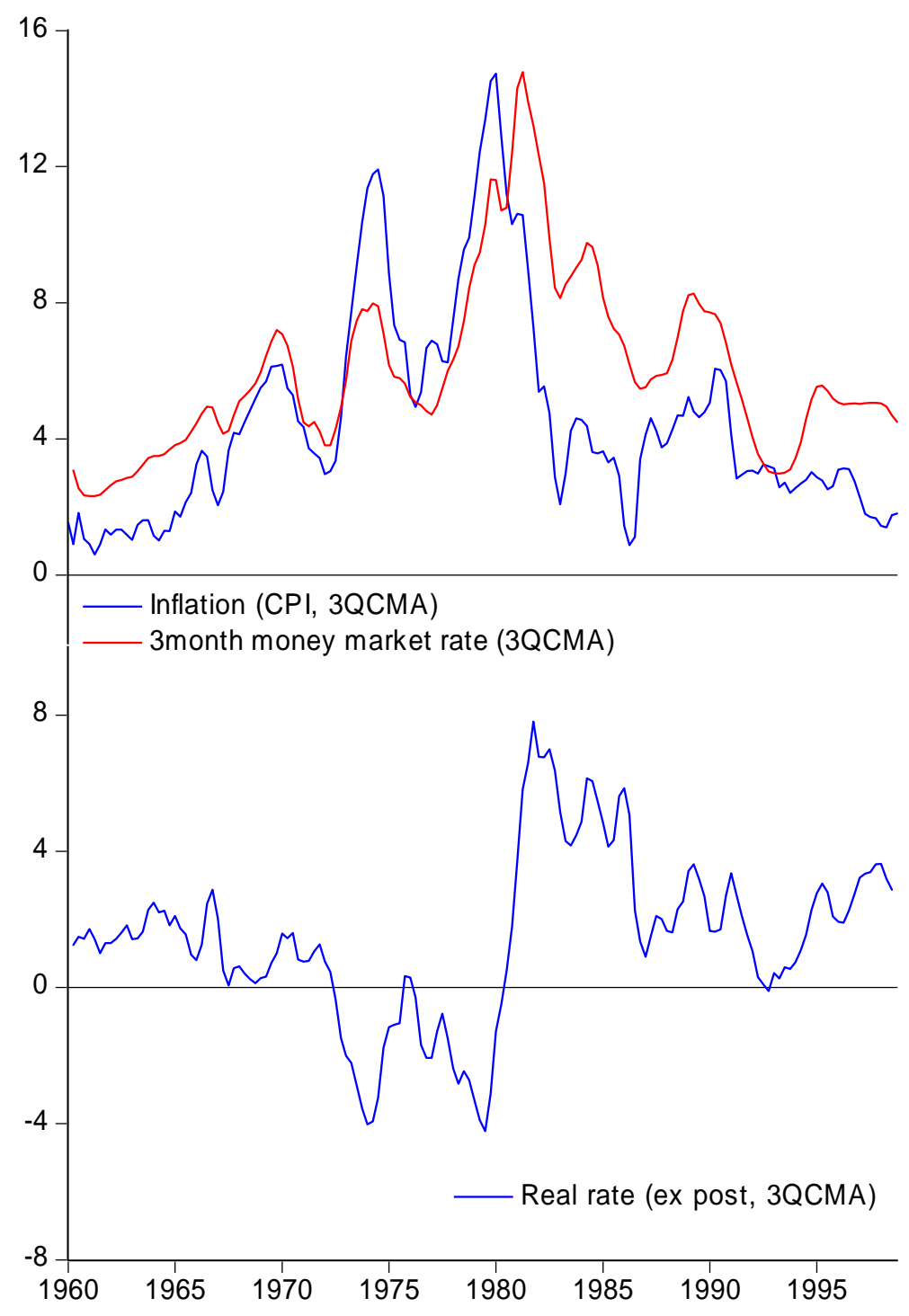


Table 5.1: Estimates of the extended reaction function, inflation forward-looking (from $t$ to $t+4)$, change in output gap from $t-4$ to $t$, real-time data

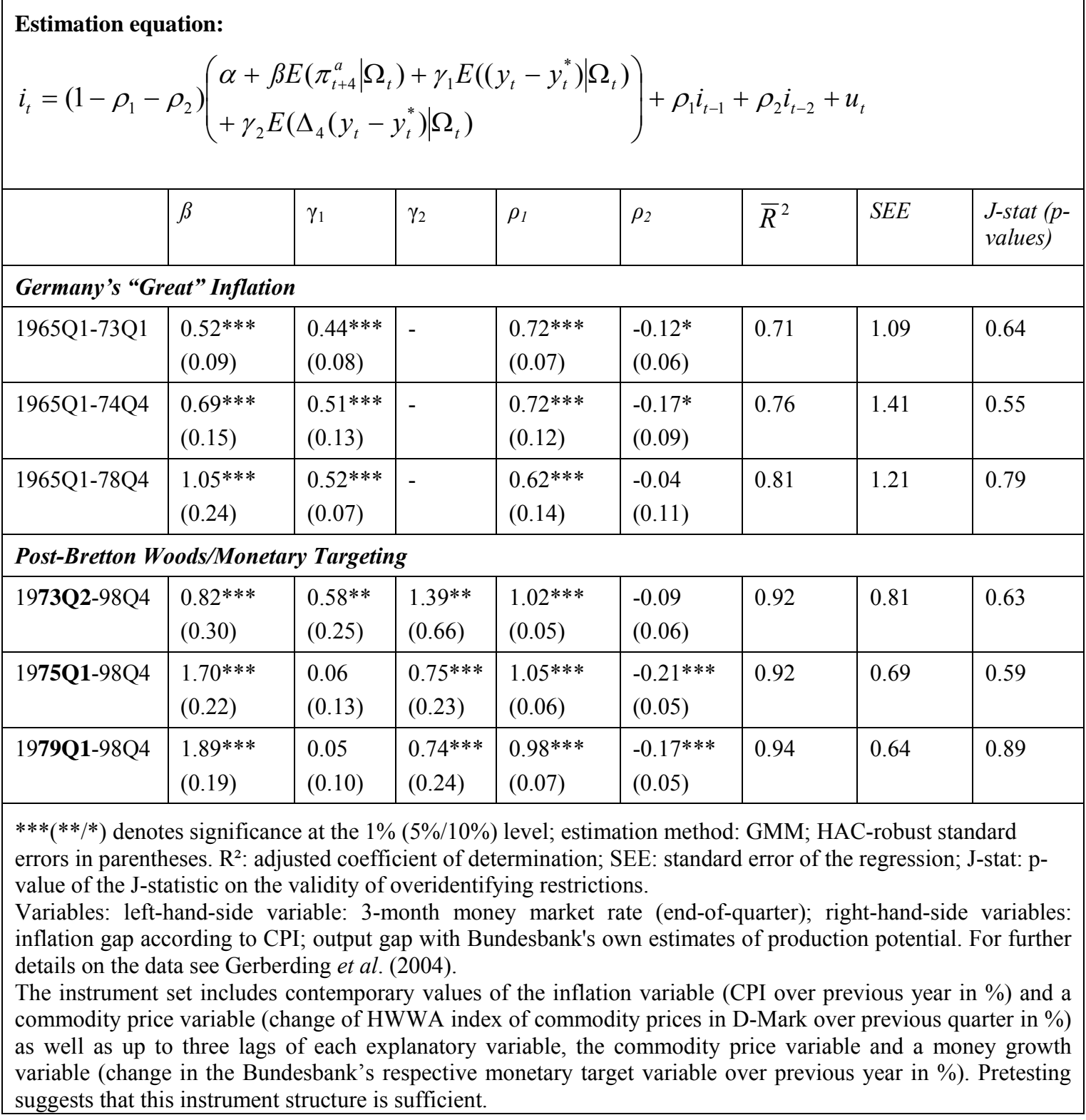


Table 5.2a: The US. Estimates of the extended reaction function, inflation forwardlooking $y-0-y$ (from $t-3$ to $t+1$ ) using real-time inflation forecast

\begin{tabular}{|c|c|c|c|c|c|c|c|c|}
\hline \multicolumn{9}{|c|}{ Estimation equation: } \\
\hline & $\beta$ & $\gamma_{1}$ & $\gamma_{2}$ & $\rho_{1}$ & Const & $\bar{R}^{2}$ & $S E E$ & $\begin{array}{l}J \text {-stat } \\
\text { (11dof) } \\
(p- \\
\text { values })\end{array}$ \\
\hline $\begin{array}{l}\text { 1970Q1- } \\
\text { 1979Q2 } \\
\mathrm{j}=1\end{array}$ & $\begin{array}{l}1.100 * * * \\
(0.114)\end{array}$ & $\begin{array}{l}0.367 * * * \\
(0.072)\end{array}$ & $\begin{array}{l}0.064 \\
(0.053)\end{array}$ & $\begin{array}{l}0.592 * * * \\
(0.098)\end{array}$ & $\begin{array}{l}0.009^{* *} \\
(0.003)\end{array}$ & 0.86 & 0.006 & $\begin{array}{l}0.11 * 34 \\
(>10 \%)\end{array}$ \\
\hline $\begin{array}{l}\text { 1970Q1- } \\
\text { 1979Q2 } \\
\mathrm{j}=4\end{array}$ & $\begin{array}{l}1.023 * * * \\
(0.128)\end{array}$ & $\begin{array}{l}0.390 * * * \\
(0.098)\end{array}$ & $\begin{array}{l}-0.013 \\
(0.026)\end{array}$ & $\begin{array}{l}0.545 * * * \\
(0.109)\end{array}$ & $\begin{array}{l}0.012 * * * \\
(0.004)\end{array}$ & 0.87 & 0.006 & $\begin{array}{l}0.15 * 34 \\
(>10 \%)\end{array}$ \\
\hline $\begin{array}{l}\text { 1983Q1- } \\
\text { 1998Q4 } \\
\mathrm{j}=1\end{array}$ & $\begin{array}{l}3.499 * * * \\
(1.150)\end{array}$ & $\begin{array}{l}0.926^{* * *} \\
(0.418)\end{array}$ & $\begin{array}{l}0.512^{* * * *} \\
(0.183)\end{array}$ & $\begin{array}{l}0.912 * * * \\
(0.028)\end{array}$ & $\begin{array}{l}-0.004 * * \\
(0.002)\end{array}$ & 0.93 & 0.004 & $\begin{array}{l}0.15 * 60 \\
(>10 \%)\end{array}$ \\
\hline $\begin{array}{l}\text { 1983Q1- } \\
\text { 1998Q4 } \\
\mathrm{j}=4\end{array}$ & $\begin{array}{l}2.721^{* * *} \\
(0.609)\end{array}$ & $\begin{array}{l}0.458 * * * \\
(0.161)\end{array}$ & $\begin{array}{l}0.122 * * * \\
(0.035)\end{array}$ & $\begin{array}{l}0.89^{* * *} \\
(0.029)\end{array}$ & $\begin{array}{l}-0.003 \\
(0.002)\end{array}$ & 0.96 & 0.003 & $\begin{array}{l}0.17 * 60 \\
(>10 \%)\end{array}$ \\
\hline \multicolumn{9}{|c|}{$\begin{array}{l}* * *(* * *) \text { denotes significance at the } 1 \%(5 \% / 10 \%) \text { level; estimation method: GMM; HAC-robust standard } \\
\text { errors in parentheses. } \mathrm{R}^{2} \text { : adjusted coefficient of determination; SEE: standard error of the regression; J-stat: p- } \\
\text { value of the J-statistic on the validity of overidentifying restrictions. } \\
\text { Variables: left-hand-side variable: } 3 \text {-month T-Bill rate; right-hand-side variables: Greenbook inflation forecasts } \\
\text { (y-o-y CPI); output gap; and y-o-y changes in the output gap. For further details on the output gap data see } \\
\text { Orphanides (2003), p. } 996 \mathrm{ff} \text {. }\end{array}$} \\
\hline
\end{tabular}


Table 5.2b: The US. Estimates of the extended reaction function, inflation forwardlooking y-o-y (from t-3 to $t+1)$

\begin{tabular}{|c|c|c|c|c|c|c|c|c|}
\hline \multicolumn{9}{|c|}{$\begin{array}{l}\text { Estimation equation: } \\
i_{t}=\left(1-\rho_{1}\right)\left(\alpha+\beta E_{t}\right.\end{array}$} \\
\hline & $\beta$ & $\gamma_{1}$ & $\gamma_{2}$ & $\rho_{1}$ & Const & $\bar{R}^{2}$ & $S E E$ & $\begin{array}{l}J \text {-stat } \\
\text { (11dof) } \\
(p- \\
\text { values) }\end{array}$ \\
\hline $\begin{array}{l}\text { 1970Q1- } \\
\text { 1979Q2 } \\
j=1\end{array}$ & $\begin{array}{l}0.619 * * * \\
(0.030)\end{array}$ & $\begin{array}{l}0.195 * * * \\
(0.040)\end{array}$ & $\begin{array}{l}0.095 \\
(0.059)\end{array}$ & $\begin{array}{l}0.458 * * * \\
(0.064)\end{array}$ & $\begin{array}{l}0.018^{* * *} \\
(0.001)\end{array}$ & 0.87 & 0.006 & $\begin{array}{l}0.22 * 34 \\
(>10 \%)\end{array}$ \\
\hline $\begin{array}{l}\text { 1970Q1- } \\
\text { 1979Q2 } \\
j=4\end{array}$ & $\begin{array}{l}0.591 * * * \\
(0.033)\end{array}$ & $\begin{array}{l}0.206^{* *} \\
(0.084)\end{array}$ & $\begin{array}{l}0.014 \\
(0.028)\end{array}$ & $\begin{array}{l}0.493 * * * \\
(0.108)\end{array}$ & $\begin{array}{l}0.018 * * * \\
(0.002)\end{array}$ & 0.86 & 0.006 & $\begin{array}{l}0.22 * 34 \\
(>10 \%)\end{array}$ \\
\hline $\begin{array}{l}\text { 1983Q1- } \\
\text { 1998Q4 } \\
j=1\end{array}$ & $\begin{array}{l}2.73^{*} \\
(1.506)\end{array}$ & $\begin{array}{l}1.406 \\
(1.035)\end{array}$ & $\begin{array}{l}0.419 * * * \\
(0.076)\end{array}$ & $\begin{array}{l}0.960 * * * \\
(0.025)\end{array}$ & $\begin{array}{l}-0.002^{*} \\
(0.001)\end{array}$ & 0.94 & 0.004 & $\begin{array}{l}0.15 * 60 \\
(>10 \%)\end{array}$ \\
\hline $\begin{array}{l}\text { 1983Q1- } \\
\text { 1998Q4 } \\
j=4\end{array}$ & $\begin{array}{l}2.040^{* * * *} \\
(0.540)\end{array}$ & $\begin{array}{l}0.475^{* *} \\
(0.221)\end{array}$ & $\begin{array}{l}0.149 * * * \\
(0.027)\end{array}$ & $\begin{array}{l}0.89^{* * *} \\
(0.029)\end{array}$ & $\begin{array}{l}-0.002 \\
(0.002)\end{array}$ & 0.96 & 0.003 & $\begin{array}{l}0.17 * 60 \\
(>10 \%)\end{array}$ \\
\hline \multicolumn{9}{|c|}{$\begin{array}{l}* * *(* * *) \text { denotes significance at the } 1 \%(5 \% / 10 \%) \text { level; estimation method: GMM; HAC-robust standard } \\
\text { errors in parentheses. } \mathrm{R}^{2}: \text { adjusted coefficient of determination; SEE: standard error of the regression; J-stat: p- } \\
\text { value of the J-statistic on the validity of overidentifying restrictions. } \\
\text { Variables: left-hand-side variable: } 3 \text {-month T-Bill rate; right-hand-side variables: inflation (y-o-y CPI); output } \\
\text { gap; and y-o-y changes in the output gap. For further details on the output gap data see Orphanides (2003), p. } \\
996 \mathrm{ff} \text {. }\end{array}$} \\
\hline
\end{tabular}


Table 5.3: The UK. Estimates of the extended reaction function, inflation forwardlooking y-o-y (from t-3 to $t+1)$

\begin{tabular}{|c|c|c|c|c|c|c|c|c|}
\hline \multicolumn{9}{|c|}{ Estimation equation: } \\
\hline & $\beta$ & $\gamma_{1}$ & $\gamma_{2}$ & $\rho_{1}$ & Const & $\bar{R}^{2}$ & SEE & $\begin{array}{l}J \text {-stat } \\
\text { (11dof) } \\
(p- \\
\text { values })\end{array}$ \\
\hline $\begin{array}{l}\text { 1970Q1- } \\
\text { 1979Q2 } \\
\mathrm{j}=1\end{array}$ & $\begin{array}{l}-0.10 \\
(0.463)\end{array}$ & $\begin{array}{l}0.007 \\
(0.34)\end{array}$ & $\begin{array}{l}0.02 \\
(0.05)\end{array}$ & $\begin{array}{l}0.869^{* * *} \\
(0.10)\end{array}$ & $\begin{array}{l}0.015^{* * *} \\
(0.005)\end{array}$ & 0.73 & 0.015 & $\begin{array}{l}0.24 * 35 \\
(>10 \%)\end{array}$ \\
\hline $\begin{array}{l}\text { 1970Q1- } \\
\text { 1979Q2 } \\
\mathrm{j}=4\end{array}$ & $\begin{array}{l}0.058 \\
(0.33)\end{array}$ & $\begin{array}{l}-0.02 \\
(0.37)\end{array}$ & $\begin{array}{l}0.07 \\
(0.083)\end{array}$ & $\begin{array}{l}0.827 * * * \\
(0.081)\end{array}$ & $\begin{array}{l}0.016^{* *} \\
(0.006)\end{array}$ & 0.74 & 0.014 & $\begin{array}{l}0.23 * 35 \\
(>10 \%)\end{array}$ \\
\hline $\begin{array}{l}\text { 1983Q1- } \\
\text { 1996Q1 } \\
\mathrm{j}=1\end{array}$ & $\begin{array}{l}1.531 \text { *** } \\
(0.14)\end{array}$ & $\begin{array}{l}-0.32 \\
(0.28)\end{array}$ & $\begin{array}{l}-0.09 \\
(0.095)\end{array}$ & $\begin{array}{l}0.70^{* * *} \\
(0.071)\end{array}$ & $\begin{array}{l}0.002 \\
(0.002)\end{array}$ & 0.92 & 0.0078 & $\begin{array}{l}0.16 * 53 \\
(>10 \%)\end{array}$ \\
\hline $\begin{array}{l}\text { 1983Q1- } \\
\text { 1996Q1 } \\
\mathrm{j}=4\end{array}$ & $\begin{array}{l}1.526^{* * *} \\
(0.156)\end{array}$ & $\begin{array}{l}-0.20 \\
(0.299)\end{array}$ & $\begin{array}{l}-0.02 \\
(0.081)\end{array}$ & $\begin{array}{l}0.72 * * * \\
(0.069)\end{array}$ & $\begin{array}{l}0.004 \\
(0.003)\end{array}$ & 0.92 & 0.0079 & $\begin{array}{l}0.16 * 53 \\
(>10 \%)\end{array}$ \\
\hline \multicolumn{9}{|c|}{$\begin{array}{l}* * *(* * / *) \text { denotes significance at the } 1 \%(5 \% / 10 \%) \text { level; estimation method: GMM; HAC-robust standard } \\
\text { errors in parentheses. } \mathrm{R}^{2} \text { : adjusted coefficient of determination; SEE: standard error of the regression; J-stat: p- } \\
\text { value of the J-statistic on the validity of overidentifying restrictions. } \\
\text { Variables: left-hand-side variable: } 3 \text {-month T-Bill rate; right-hand-side variables: inflation (y-o-y CPI); output } \\
\text { gap; and y-o-y changes in the output gap. For further details on the output gap data see Nelson and Nikolov } \\
\text { (2003). }\end{array}$} \\
\hline
\end{tabular}

